\title{
Article
}

\section{The Legacy of the Idrija Mine Twenty-Five Years after Closing: Is Mercury in the Water Column of the Gulf of Trieste Still an Environmental Issue?}

\author{
Elena Pavoni ${ }^{1}$, Elisa Petranich ${ }^{1}$, Sergio Signore ${ }^{2}$, Giorgio Fontolan ${ }^{1} \mathbb{D}$ and Stefano Covelli ${ }^{1, *(\mathbb{D})}$ \\ 1 Dipartimento di Matematica e Geoscienze, Università Degli Studi di Trieste, Via Weiss 2, 34128 Trieste, Italy; \\ epavoni@units.it (E.P.); epetranich@units.it (E.P.); fontolan@units.it (G.F.) \\ 2 Autorità di Sistema Portuale del Mare Adriatico Orientale-Porto di Trieste, Via Karl Ludwig Von Bruck 3, \\ 34144 Trieste, Italy; sergio.signore@porto.trieste.it \\ * Correspondence: covelli@units.it; Tel.: +39-040-558-2031
}

Citation: Pavoni, E.; Petranich, E.; Signore, S.; Fontolan, G.; Covelli, S. The Legacy of the Idrija Mine Twenty-Five Years after Closing: Is Mercury in the Water Column of the Gulf of Trieste Still an Environmental Issue? Int. J. Environ. Res. Public Health 2021, 18, 10192. https:// doi.org/10.3390/ijerph181910192

Academic Editors: Stefania Venturi, Barbara Nisi, Alessandro Acquavita, Sergio Calabrese and Jacopo Cabassi

Received: 3 August 2021

Accepted: 23 September 2021

Published: 28 September 2021

Publisher's Note: MDPI stays neutral with regard to jurisdictional claims in published maps and institutional affiliations.

Copyright: (c) 2021 by the authors. Licensee MDPI, Basel, Switzerland. This article is an open access article distributed under the terms and conditions of the Creative Commons Attribution (CC BY) license (https:// creativecommons.org/licenses/by/ $4.0 /)$.

\begin{abstract}
Mercury (Hg) contamination in the Gulf of Trieste (northern Adriatic Sea) due to mining activity in Idrija (Slovenia) still represents an issue of environmental concern. The Isonzo/Soča River's freshwater inputs have been identified as the main source of $\mathrm{Hg}$ into the Gulf, especially following periods of medium-high discharge. This research aims to evaluate the occurrence and distribution of dissolved (DHg) and particulate (PHg) Hg along the water column in the northernmost sector of the Gulf, a shallow and sheltered embayment suitable for the accumulation of fine sediments. Sediment and water samples were collected under unperturbed and perturbed environmental conditions induced by natural and anthropogenic factors. Mercury in the sediments $\left(0.77-6.39 \mu \mathrm{g} \mathrm{g}^{-1}\right)$ and its relationship to grain size were found to be consistent with previous research focused on the entire Gulf, testifying to the common origin of the sediment. Results showed a notable variability of $\mathrm{DHg}$ (<LOD-149 $\mathrm{ng} \mathrm{L}^{-1}$ ) and PHg (0.39-12.5 $\left.\mathrm{ng} \mathrm{L}^{-1}\right)$ depending on the interaction between riverine and marine hydrological conditions. Mercury was found to be mainly partitioned in the suspended particles, especially following periods of high discharge, thus confirming the crucial role of the river inputs in regulating $\mathrm{PHg}$ distribution in the Gulf.
\end{abstract}

Keywords: mercury; sediments; water column; suspended particulate matter

\section{Introduction}

Among potentially toxic trace elements (PTEs) found in the environment, mercury $(\mathrm{Hg})$ is a focus of global concern and was included among the World Health Organization's top ten "chemicals of concern" in 2017 [1].

Mining activity and related mineral processing, as well as coal combustion and industrial activities (e.g., chlor-alkali plants), are generally considered among the major anthropogenic sources of $\mathrm{Hg}$ [2] and other PTEs in the environment. Atmospheric deposition, erosion and riverine inputs of suspended particulate matter (SPM) contribute to convey $\mathrm{Hg}$ in estuaries and marine-coastal areas where the element is accumulated in the bottom sediments [3,4]. Indeed, the sediment compartment may act both as a sink and a secondary source of contamination due to resuspension events and remobilisation processes with the subsequent release of both dissolved and particulate $\mathrm{Hg}$ species into the water column $[5,6]$.

Moreover, the top few centimetres of sediment often represent the primary site for the production of methylmercury $(\mathrm{MeHg}$ ) [7-10], the organic form of $\mathrm{Hg}$ of main concern due to its high toxicity and bioaccumulation potential in the aquatic food chain $[8,11-13]$.

In the offshore marine sediments of the Mediterranean Sea, $\mathrm{Hg}$ reaches concentrations (avg. 0.10-0.20 $\mathrm{g} \mathrm{g} \mathrm{g}^{-1}$, [14]) which testify to an enrichment with respect to the world-wide natural background $\left(0.03 \mu \mathrm{g} \cdot \mathrm{g}^{-1}\right)$ [15] due to both natural and anthropogenic sources. 
Among the most contaminated areas in Italy, the Venice Lagoon, the Marano and Grado Lagoon and the Gulf of Trieste are located in the northern area of the Adriatic Sea [16-20] where marine sediments showed the highest amount of $\mathrm{Hg}\left(0.05-8.63 \mu \mathrm{g} \cdot \mathrm{g}^{-1},[21]\right)$, diminishing towards the central and southern sector of the same basin [21].

It has been demonstrated that $\mathrm{Hg}$ contamination in the Gulf of Trieste mostly originates from riverine inputs of the Isonzo/Soča River e.g., [19,22,23] draining Hg-enriched river banks and floodplain deposits along the river basin hosting the second largest $\mathrm{Hg}$ mine worldwide [24-26]. Indeed, over 500 years of cinnabar ( $\mathrm{HgS})$ extraction activity at the Idrija mining district (western Slovenia, Figure 1) has led to Hg contamination of multiple environmental matrices both in the areas surrounding the mine and far from this primary source $[24,25,27-29]$.

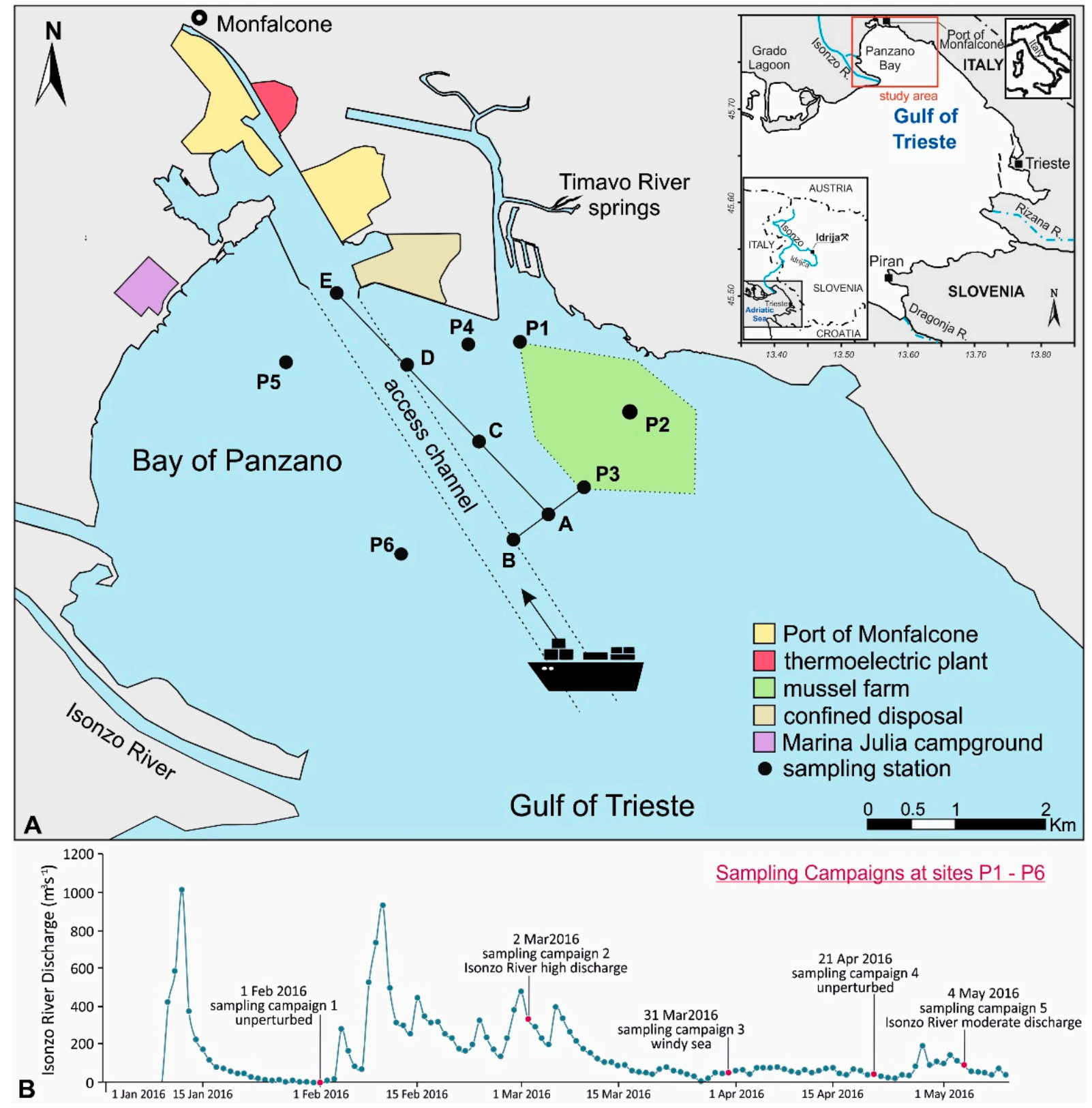

Figure 1. (A). Map of the study area and location of the sampling sites near the main access channel to the Port of Monfalcone (Bay of Panzano, Gulf of Trieste). (B). Isonzo River daily discharge $\left(\mathrm{m}^{3} \mathrm{~s}^{-1}\right)$ from 1 January 2016 to 10 May 2016.

In the Gulf of Trieste, the occurrence and behaviour of $\mathrm{Hg}$ have been the main topics of several studies focused on coastal sediment contamination [19,30], transport and distribu- 
tion of $\mathrm{Hg}$ associated with the SPM at the Isonzo River mouth [22,23] as well as $\mathrm{Hg}$ cycling at the sediment-water interface [31,32]. However, little information is currently available on the occurrence of dissolved $(\mathrm{DHg})$ and particulate $(\mathrm{PHg}) \mathrm{Hg}$ in the northernmost sector of the Gulf of Trieste (Bay of Panzano), where the main access channel approaching the Port of Monfalcone is located. This embayment represents a suitable environment for the accumulation of suspended particles enriched in $\mathrm{Hg}$.

Moreover, there is growing interest on the part of national and local authorities regarding the potential impact of $\mathrm{Hg}$ in the water column related to the resuspension of sediments due to future dredging operations needed to allow the navigation of ships approaching the port area.

In this context, the primary aim of this research is to evaluate the occurrence of $\mathrm{Hg}$ in the surface sediments as well as its partitioning behaviour between solid and dissolved phases along the water column under both unperturbed and perturbed environmental conditions, the latest induced by both natural and anthropogenic factors. This study provides a snapshot of the present situation and a baseline for $\mathrm{Hg}$ in the water column, useful for future evaluation of the impact of $\mathrm{Hg}$ in this coastal environment.

\section{Materials and Methods}

\subsection{Environmental Setting}

The Gulf of Trieste is a semi-closed shallow-water basin located in the northern Adriatic Sea with a maximum water depth of $25 \mathrm{~m}$ in its central sector. Water salinity in the Gulf typically ranges between 25 and 38 PSU (using the Practical Salinity Scale), whereas the seawater temperature ranges between 5 and $26{ }^{\circ} \mathrm{C}$ following the seasons [33]. The water circulation in the Gulf is mainly dominated by the anticlockwise circulation pattern of the Adriatic Sea and is controlled by tides, seasonal variations in the freshwater inflow, and winds (Bora E-NE, Libeccio SW and Scirocco SE) [34], which significantly influence the vertical water circulation [35].

In the Gulf of Trieste, the Isonzo/Soča River is the main input of both freshwater (average discharge of $83 \mathrm{~m}^{3} \cdot \mathrm{s}^{-1}$, [33]) and SPM, whose distribution is regulated by the interaction between meteo-marine and riverine hydrological conditions.

The Isonzo River is known as the primary source of $\mathrm{Hg}$ into the Gulf of Trieste and the element at the river mouth was found to be almost completely partitioned in the SPM [36]. In this context, the river freshwater inputs play a crucial role in the occurrence and distribution of PHg both under periods of medium-high river discharge [22] and during extreme river plume events when the influx of $\mathrm{PHg}$ into the Gulf ranged between 37.0 and $112 \mathrm{ng} \cdot \mathrm{L}^{-1}$ [23].

Regarding the surface sediment of the Gulf of Trieste, the highest concentrations of $\mathrm{Hg}$ were found at the Isonzo River mouth $\left(23.3 \mu \mathrm{g} \cdot \mathrm{g}^{-1}\right)$ due to the prevalence of cinnabar particles in the coarser sandy-silty fraction of the sediment [19,37]. Although the amount of $\mathrm{Hg}$ in the sediment decreases with increasing distance from the river mouth [19], extensive $\mathrm{Hg}$ contamination may also be present in the nearshore areas of the northernmost sector of the Gulf of Trieste (Bay of Panzano), a shallow and sheltered embayment promoting the accumulation of fine sediments and contaminants (Figure 1). The area is affected by several anthropogenic activities including agricultural and industrial settlements in the hinterland and tourist and mussel farming areas along the coast. An additional source of potential contamination is represented by the city of Monfalcone, which is home to a thermoelectric plant, several coal, petroleum and other cargo handling equipment and an extended port area which can be reached through a main channel located between the Isonzo River mouth and a mussel farm (Figure 1). Industrial activity in the port area was thought to be a potential source of organic contaminants (PAH and PCB) in the sediments of the Bay of Panzano [38] and residues from antifouling paints used on boats have been identified as a source of PTEs (e.g., $\mathrm{Cu}$ and $\mathrm{Zn}$ ) [38,39]. 


\subsection{Sampling Strategy}

Sampling operations for the collection of sediment and water samples were performed at six sites (P1-P6) located in the vicinity of the main access channel to the Port of Monfalcone (Figure 1). With the exception of site P6 (located in the offshore marine area of the Bay of Panzano), all the sampling stations are representative of different targets: mussel farming (P1, P2 and P3), marine phanerogam meadows (P4) and tourist attractions along the beach (P5). Moreover, site $\mathrm{P} 4$ is located in the marine coastal sector adjacent to a confined disposal site for the storage of dredged sediments (Figure 1). These targets could be affected by both the Isonzo River plume events and the resuspension of fine $\mathrm{Hg}$ enriched particles induced by natural and anthropogenic factors (e.g., dredging).

Daily average discharge from the Isonzo River at the time of sampling was recorded from the gauging station of Pieris (Gorizia) located approximately $15 \mathrm{~km}$ upstream from the river mouth (Table 1). Vertical profiles of salinity (PSU), temperature $\left({ }^{\circ} \mathrm{C}\right)$ and turbidity (NTU) were recorded by means of a CTD multiprobe (Hydrolab H20 Multiprobe, OTT HydroMet, Loveland, CO, USA) with a 0.10 dbar pressure step and a sampling rate of $1 \mathrm{~s}$ ) before sampling. Two water samples were collected using a Niskin bottle (Hydro-Bios Apparatebau $\mathrm{GmbH}$, Altenholz, Germany) from the surface (0-0.5 m depth) and bottom ( $0.50 \mathrm{~m}$ from the bottom sediment) water layers, respectively. Sampling operations were performed during five sampling campaigns carried out under different environmental conditions including (i) unperturbed conditions characterised by low river flow, the absence of wind and good weather (sampling campaigns 1 and 4); (ii) perturbed conditions induced by natural factors such as periods of moderate-high river discharge (sampling campaigns 2 and 5) and conditions of windy sea (sampling campaign 3); (iii) perturbed conditions induced by anthropogenic activities (the movement of ships, sampling campaign 6) (Table 1). Although sampling campaigns 2 and 5 were both performed following a period of moderate-high river discharge, it should be pointed out that the river discharge was notably low during the sampling campaign $5\left(87.3 \mathrm{~m}^{3} \mathrm{~s}^{-1}\right)$ compared to sampling campaign $2\left(328 \mathrm{~m}^{3} \mathrm{~s}^{-1}\right)$, which was performed following a period of particularly heavy river flow (Figure 1; Table 1).

Table 1. Environmental conditions and Isonzo River daily discharge $\left(\mathrm{m}^{3} \mathrm{~s}^{-1}\right)$ during the six sampling campaigns performed to collect surface and bottom water samples at the six investigated sites in the Bay of Panzano.

\begin{tabular}{ccccc}
\hline \multicolumn{2}{c}{ Sampling Campaign } & Environmental Conditions & Isonzo River Daily Discharge $\mathbf{~ ( m}^{\mathbf{3}} \mathbf{s}^{-\mathbf{1})}$ & Sampling Sites \\
\hline 1 & 1 February 2016 & unperturbed & 4.45 & P1-P6 \\
2 & 2 March 2016 & Isonzo River high discharge & 328 & P1-P6 \\
3 & 31 March 2016 & windy sea & 45.8 & P1-P6 \\
4 & 21 April 2016 & unperturbed & 89.0 & P1-P6 \\
5 & 4 May 2016 & Isonzo River moderate discharge & 72.0 & P1-P6 \\
6 & 15 April 2016 & after a ship with large draught & A-E and P3 \\
\hline
\end{tabular}

Water samples for the analytical determination of DHg were filtered (Millipore Millex HA, $0.45 \mu \mathrm{m}$ pore size, Millipore, Burlington, MA, USA) in the field, collected into preconditioned borosilicate glass containers and immediately oxidised by adding bromine chloride (BrCl, Hg-free from Brooks Rand Instruments, Seattle, WA, USA, $0.5 \% v / v$, until the sample turned the colour yellow) according to the EPA Method 1631e [40]. Additional $2 \mathrm{~L}$ water samples were taken to the laboratory where the SPM was separated from the dissolved fraction by vacuum filtration.

During sampling campaign 1, surface sediments were also collected at each site (P1-P6) using a stainless steel Van Veen grab (1.7 L, Hydro-Bios Apparatebau GmbH, Altenholz, Germany)). Three distinct aliquots of sediment were collected and a stainless steel spoon was employed to rapidly scrape off the first $2 \mathrm{~cm}$ of the sediment surface which was then homogenised in situ to get a composite sample, stored in appropriate containers and transported to the laboratory. 
In addition, three multiprobes were placed at sites P2 (approximately $2 \mathrm{~m}$ depth and at the bottom, Aanderaa RCM9, Aanderaa Data Instruments AS, Bergen, Norway) and P3 (approximately $2 \mathrm{~m}$ depth, Hydrolab DS5 OTT HydroMet, Loveland, CO, USA) in order to achieve in situ continuous measurements of temperature $\left({ }^{\circ} \mathrm{C}\right.$ ), salinity (PSU, Practical Salinity Unit) and turbidity (NTU, Nephelometric Turbidity Unit) along the water column.

Sampling campaign 6 was performed at different sites (A-E and P3) towards the main access channel to the Port of Monfalcone in order to compare unperturbed and perturbed conditions which occurred before and after a large draught ship $(8 \mathrm{~m})$ had entered and subsequently left the area (Figure 1; Table 1). To achieve this objective, the area (site A) located between the mussel farm (site P3) and the navigation channel (site B) was selected as the most representative (Figure 1). There (sites A, B and P3), as well as along the main channel to the port area (sites C-E), turbidity vertical profiles were recorded before and after a ship had entered and left the area.

In detail, the unperturbed condition was evaluated by means of turbidity vertical profiles recorded at sites P3 and B before the ship had entered the selected area. After the ship had passed by, turbidity profiles were recorded approximately every $10 \mathrm{~min}$ at site $\mathrm{A}$ in order to evaluate variations in the turbidity values along the water column over time. In addition, two water samples for the analytical determination of $\mathrm{DHg}$ and $\mathrm{PHg}$ were collected at site $\mathrm{A}$, one at the bottom and one at approximately $7 \mathrm{~m}$ depth, where the maximum turbidity zone was observed. Subsequently, turbidity vertical profiles were also recorded following the ship at sites $\mathrm{C}, \mathrm{D}$ and $\mathrm{E}$, towards the main channel to the port area and once again at site $\mathrm{P} 3$ where additional water samples were collected at the bottom and at approximately $7 \mathrm{~m}$ depth, respectively.

\subsection{Surface Sediments: Grain Size Analysis and Total Hg Content}

For grain size analysis, 15-20 g of fresh sediment sample were processed using hydrogen peroxide $\left(\mathrm{H}_{2} \mathrm{O}_{2}, 10 \%\right)$ for $24 \mathrm{~h}$ to eliminate most of the organic matter, and then wet-sieved using a $2 \mathrm{~mm}$ sieve. The resulting $<2 \mathrm{~mm}$ fraction was analysed by means of a laser granulometer (Malvern Mastersizer 2000, Malvern Panalytical Ltd., Malvern, UK).

A subsample of the sediment was frozen and freeze-dried (CoolSafe 55-4 SCANVAC, Scientific Laboratory Supplies Ltd., Nottingham, UK), homogenised and ground for $\mathrm{Hg}$ determination. Total $\mathrm{Hg}$ was determined by means of a Direct Mercury Analyser (DMA-80, Milestone, Sorisole, Italy) according to the EPA Method 7473 [41]. Three replicates were analysed for each sediment sample and the quality of the analysis was evaluated by means of certified reference material (PACS-3 Marine Sediment CRM, NRCC, Whitehorse, YT, Canada), obtaining acceptable recoveries ranging between 88 and $101 \%$. The limit of detection (LOD) was approximately $0.005 \mathrm{ng}$ and the precision of the analysis expressed as RSD $\%$ was $<2 \%$.

\subsection{Analytical Determination of Particulate and Dissolved $\mathrm{Hg}$}

The SPM concentrations were determined by vacuum filtration on pre-conditioned and pre-weighed (Mettler, precision $0.00001 \mathrm{~g}$ ) Millipore HA membrane filters (ø $47 \mathrm{~mm}$, $0.45 \mu \mathrm{m}$ pore size). Filters were dried at room temperature to avoid $\mathrm{Hg}^{0}$ volatilisation due to heat sources and then stored in air-tight containers over silica gel for $4-5$ days, thereby protecting them from humidity in the air. Filters were acid-digested in a closed microwave system (Multiwave PRO, Anton Paar GmbH, Graz, Austria) using aqua regia (suprapure $\mathrm{HCl} \geq 37 \% \mathrm{VWR}$ and $\mathrm{HNO}_{3} \geq 69 \% \mathrm{VWR}$, 3:1) following the modified EPA Method 3052 [42]. The obtained solutions were diluted up to a volume of $25 \mathrm{~mL}$ by adding Milli-Q water and appropriately stored before analysis.

The analytical determination of $\mathrm{Hg}$ in the dissolved $(\mathrm{DHg})$ and in the SPM $(\mathrm{PHg})$ fractions was performed by means of Cold Vapor Atomic Fluorescence Spectrometry coupled with a gold trap preconcentration system (CV-AFS Mercur, Analytic Jena $\mathrm{GmbH}$, Jena, Germany). Water samples were analysed following the EPA Method 1631e [40] which requires a pre-reduction using $\mathrm{NH}_{2} \mathrm{OH}-\mathrm{HCl}(250 \mu \mathrm{L} / 100 \mathrm{~mL}$ sample) until the yellow 
colour disappeared, followed by a reduction with $\mathrm{SnCl}_{2}$ (Sigma-Aldrich 2\% in $\mathrm{HCl} 2 \%$ ). The instrument was calibrated using standard solutions obtained via dilution from NIST 3133 certified solution and acidified with $\mathrm{BrCl}(0.5 \%, v / v)$. Certified reference material (ORMS-5 CRM, Brantford, ON, Canada) was analysed in the same batch as the water samples for quality control and an acceptable recovery was obtained $(105 \%)$. The limit of detection was $0.60 \mathrm{ng} \mathrm{L}^{-1}$ and the precision of the analysis expressed as RSD $\%$ was $<3 \%$.

\subsection{Exploratory Multivariate Data Analysis}

Principal component analysis (PCA) was used as an unsupervised exploratory chemometric tool to evaluate the relationships within samples (PC scores and score plot), within variables (PC loadings and loading plot) and between samples and variables (biplot) [43] In detail, PCA was performed on physico-chemical parameters (salinity, temperature, SPM concentration and river discharge), $\mathrm{PHg}$ and $\mathrm{DHg}$ observed at the six investigated sites (P1-P6) under different environmental conditions (sampling campaigns 1-5). Column autoscaling was applied to data matrices to minimise systematic differences between variables [44] and multivariate data processing was performed using the CAT (Chemometric Agile Tool) package, based on the R platform (The R Foundation for Statistical Computing, Vienna, Austria) and freely distributed by Gruppo Italiano di Chemiometria (Italy) [45].

\section{Results and Discussion}

\subsection{Physico-Chemical Parameters of the Water Column}

Riverine inputs of suspended particles play a major role in the transport of $\mathrm{Hg}$ and other PTEs in estuarine and marine-coastal environments [46-48]. In these ecosystems, the composition of the SPM may be affected by several factors including hydrodynamic conditions, interactions between freshwater and saltwater, adsorption/desorption processes, sedimentation and resuspension of bottom sediments [46]. In this context, the physicochemical boundary conditions along the water column (e.g., temperature, salinity, turbidity, $\mathrm{pH}$, redox potential, dissolved oxygen) may affect $\mathrm{Hg}$ partitioning behaviour between solid and dissolved phases as well as its speciation, mobility and bioavailability [47].

A summary of the basic physico-chemical parameters (salinity, temperature and turbidity) measured along the water column at the six investigated sites (P1-P6) under different environmental conditions (sampling campaigns 1-5) is reported in Figure S1. Two distinct water masses were observed under unperturbed conditions (sampling campaigns 1 and 4) as a result of the interaction between river freshwater and seawater. Although slightly higher salinity values were recorded in the surface water in April (sampling campaign 4) at sites P2, P3 and P4 (31-33 PSU), brackish salinity values were generally observed at the other sites (22-28 PSU) increasing with depth and reaching typical marine salinity values at the bottom (36-37 PSU).

The river freshwater input was especially evident in March during sampling campaign 3 at site P6 and sampling campaign 2, which was performed following a period of intense discharge from the Isonzo River. Indeed, brackish water down to a depth of $1 \mathrm{~m}$ (ranging overall between 14 at site P1 and 26 at site P6) along with a sharp deeper halocline was observed at all the investigated sites (Figure S1).

Conversely, brackish water (18 PSU) was observed only at sites P1 and P4 in May during sampling campaign 5, most likely due to a generally lower river discharge $\left(87.3 \mathrm{~m}^{3} \mathrm{~s}^{-1}\right.$ at the time of sampling) if compared to that seen in March $\left(328 \mathrm{~m}^{3} \mathrm{~s}^{-1}\right.$, sampling campaign 2) (Table 1; Figure 1).

Temperature showed slight variations along the water column and among different sampling campaigns (Figure S1). The lowest values were recorded in the surface water in February and March $\left(10.9 \pm 0.9\right.$ and $10.6 \pm 0.5^{\circ} \mathrm{C}$ during sampling campaigns 1 and 2, respectively) and comparable values were measured at the bottom ( $9.43 \pm 0.23$ and $10.2 \pm 0.1^{\circ} \mathrm{C}$ during sampling campaigns 1 and 2, respectively). Conversely, higher values of temperature were observed in April and May, both in the surface water $(15.8 \pm 0.5$ 
and $15.8 \pm 0.4{ }^{\circ} \mathrm{C}$ during sampling campaigns 4 and 5, respectively) and at the bottom (15.0 \pm 0.5 and $14.6 \pm 0.3^{\circ} \mathrm{C}$ during sampling campaigns 4 and 5, respectively).

Turbidity showed relatively low values in February (sampling campaign 1) ranging between 1.10 and 21.0 NTU in the surface water (at sites P1 and P6, respectively) and generally decreased with increasing depth reaching values $<10$ NTU most likely due to mixing and dilution processes between different water masses. Surprisingly, relatively low values of turbidity were also observed during the sampling campaigns performed following periods of high and moderate discharge from the Isonzo River (Figure S1) with the only exception being site P2 in May (38.9 and 20.0 NTU in the surface and bottom water, respectively). The maximum turbidity values were observed in April (sampling campaign 4) in the surface water at sites P1 (67.1 NTU) and P2 (58.2 NTU), decreasing with increasing depth at each sampling site (Figure S1). In this case, the relatively elevated turbidity values may be related to enhanced biological activity during late spring [49], in particular at the mussel farm. The only exception was the vertical profile recorded at sites P3 and P5 where almost constant values of turbidity were observed along the water column (approximately 15 and 25 NTU).

Moreover, turbidity vertical profiles recorded before and after a large draught ship had passed by (sampling campaign 6, Figures 1 and 2) showed that before the ship had approached, turbidity was found to be extremely low ( $<5$ NTU) at sites P3 and B, testifying to unperturbed conditions. A clear increment of the turbidity values was evident immediately after the ship had passed site A and the maximum values (20-25 NTU) were recorded at approximately $7 \mathrm{~m}$ depth about $30 \mathrm{~min}$ after the ship had sailed out of the area (Figure 2). However, the perturbation induced by the movement of the ship did not reach particularly high values of turbidity and lasted only a brief period of time. Indeed, unperturbed conditions were restored in less than two hours as highlighted by the vertical profile recorded at site P3 ( $<5 \mathrm{NTU})$ (Figure 2). In this context, the characteristics of both the ship (e.g., draught, speed) and the location (e.g., water depth, distance to shore, sediment grain size) may represent the two main factors governing the amount of the resuspended material [50].

Additional information was provided by the measurements of the Isonzo River discharge as well as the continuous measurements of salinity, temperature and turbidity recorded at the beginning of March at sites P2 (surface and bottom) and P3 (surface) (Figure S2). The effects induced by the high river discharge at the beginning of March (471 and $391 \mathrm{~m}^{3} \mathrm{~s}^{-1}$ ) were clearly evident at both sites P2 and P3, where a decrease in the salinity values corresponded to a decrease in temperature in the surface water, most likely due to notable freshwater input. Regarding turbidity, relatively low values were observed in the surface water reaching maximum values of 9.60 (at site P2) and 15.6 NTU (at site P3) which appeared to persist for a brief period of time. Indeed, unperturbed conditions were rapidly restored according to the results obtained from the comparison between unperturbed and perturbed conditions before the ship had approached and after it had sailed out of the area (Figure 2 and Figure S2).

Conversely, a notable increase in the turbidity values was observed at the bottom at site P2 (maximum value of $112 \mathrm{NTU}$ ). However, this perturbation lasted approximately $24 \mathrm{~h}$, suggesting that it may have been related to technical operations at the mussel farm such as the lowering of a boat's anchor.

\subsection{Surface Sediments: Grain-Size and Hg Content}

The surface sediments were found to be heterogeneous in terms of grain-size composition, although those collected at the mussel farm (P1, P2 and P3) showed a very similar grain-size spectra and composition (Figure 3). According to the classification proposed by Shepard [51], the surface sediments consisted predominantly of silt (23.3-82.8\%), followed by sand (5.01-73.8\%) and clay (2.87-14.5\%). The silty fraction clearly prevailed in the sediment collected at the mussel farm (sites P1, P2 and P3), followed by the offshore marine sector (site P6) and, to a lesser extent, site P4. Conversely, the surface sediment collected at 
site P5 showed the highest content of sand (73.8\%) most likely due to its location close to the coast and the relatively shallow waters (3-4 $\mathrm{m}$ ) and high wave energy which favour the settling of coarser particles in suspension (Figure 3).

B

before ship approached turbidity (NTU)

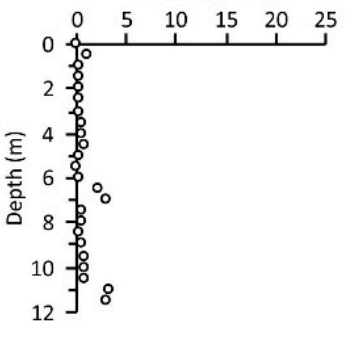

A

5 min after ship passed by turbidity (NTU)

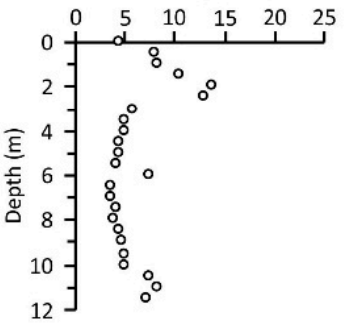

C
P3

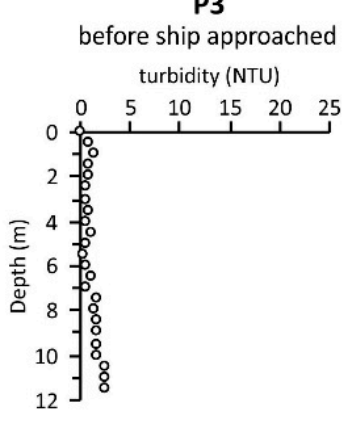

A

10 min after ship passed by turbidity (NTU)

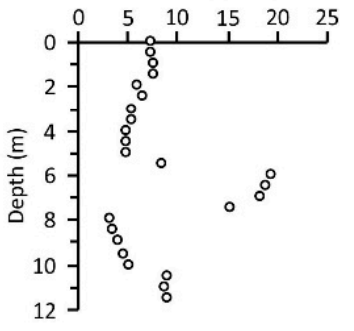

D

60 min after ship passed by - 9.34 AM $\quad 70$ min after ship passed by

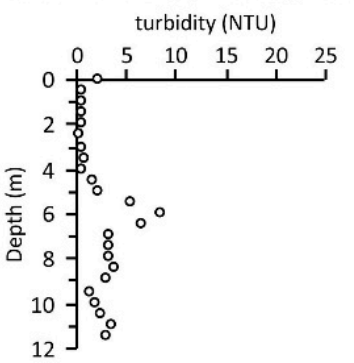
turbidity (NTU)

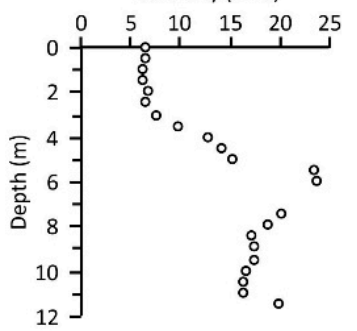

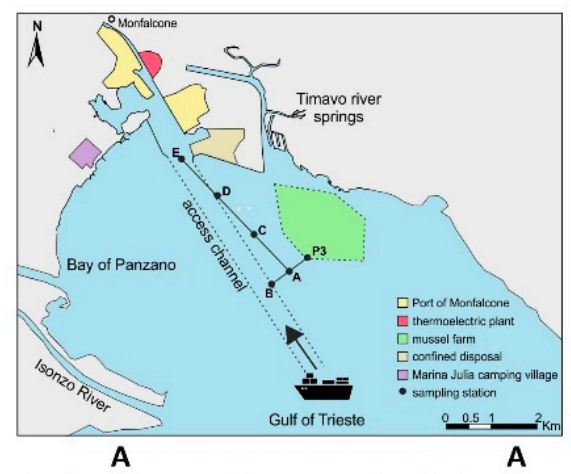

20 min after ship passed by turbidity (NTU)

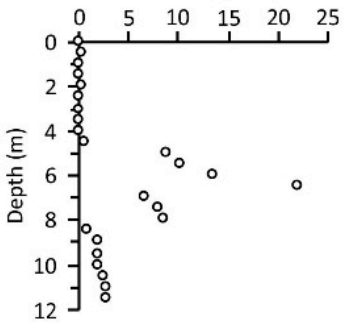

E

$80 \mathrm{~min}$ after ship passed by turbidity (NTU)

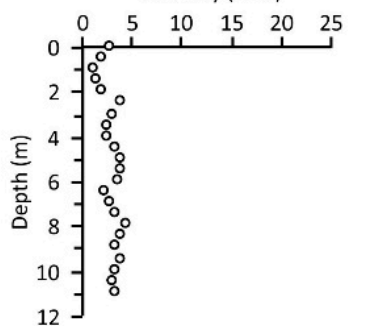

$30 \mathrm{~min}$ after ship passed by turbidity (NTU)

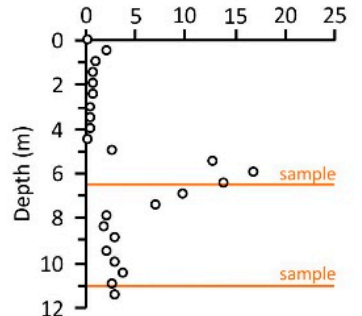

P3

$2 \mathrm{~h}$ after ship passed by turbidity (NTU)

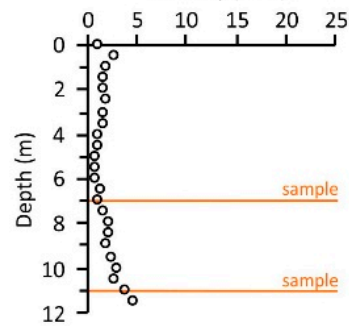

Figure 2. Turbidity (NTU) vertical profiles recorded at different sites in the area located between site P3 and the navigation channel before a large draught ship had entered and after it have left the area towards the main access channel to the Port of Monfalcone (sampling campaign 6). Water samples were collected at different depths (yellow lines) at sites A and P3 for the determination of both $\mathrm{DHg}$ and $\mathrm{PHg}$.

The $\mathrm{Hg}$ concentration in the investigated surface sediments varied between 0.77 (site P1) and 6.39 (site P6) $\mu \mathrm{g} \mathrm{g}^{-1}$ and the grain-size composition was consistent with previous research focused on the main channel approaching the Port of Monfalcone [30] (Table 2) showing that the surface sediments were dominated by silt, and Hg ranged between 0.30 and $13.5 \mu \mathrm{g} \mathrm{g}^{-1}$, decreasing from the offshore area to the innermost sector of the access channel to the port area [30]. 

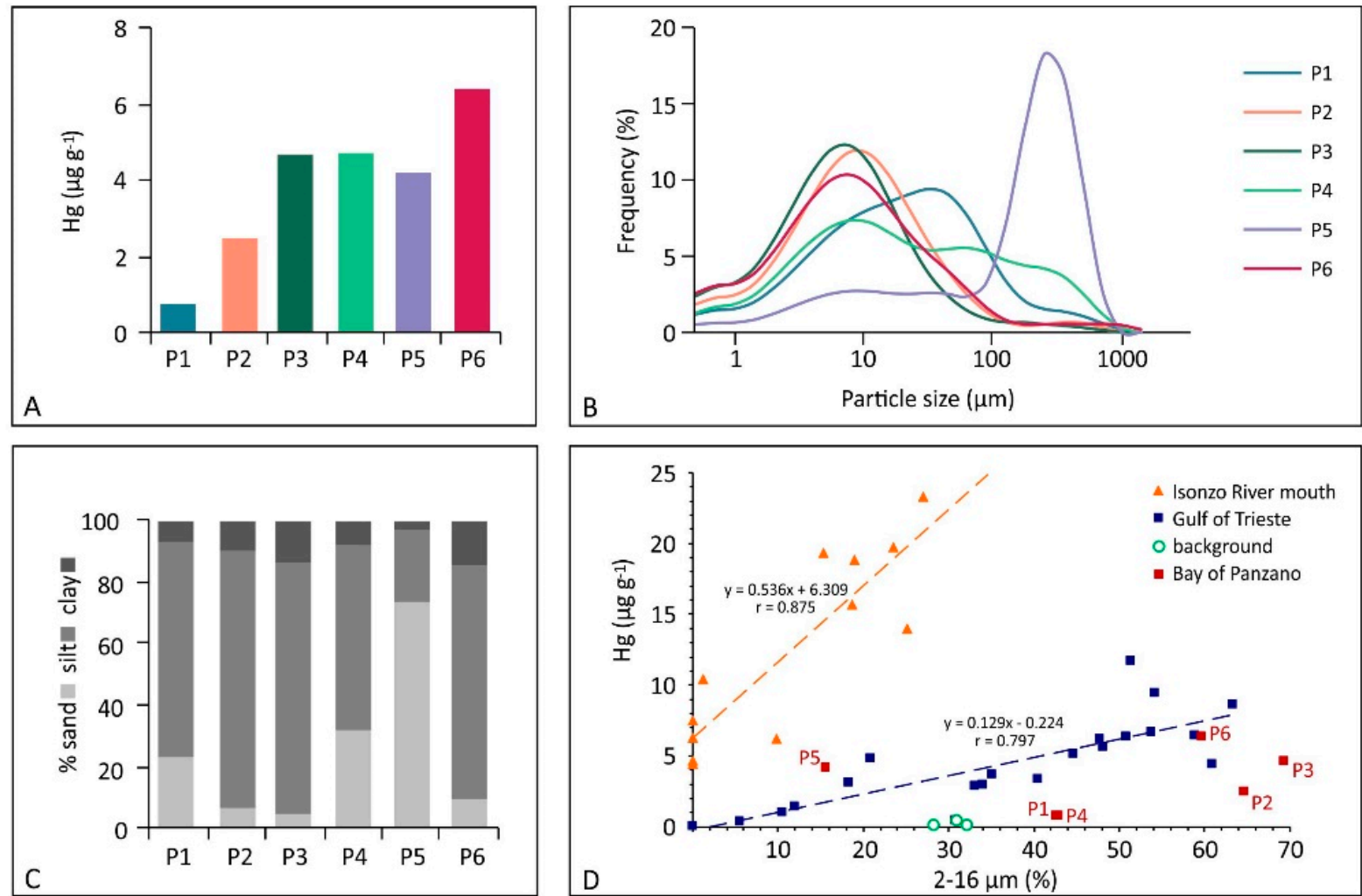

Figure 3. (A) Concentration of $\mathrm{Hg}\left(\mu \mathrm{g} \mathrm{g}^{-1}\right)$ in the surface sediments collected at the six investigated sites (P1-P6) in the Bay of Panzano; (B) Grain size spectra of the sediment samples; (C) Grain size composition of the sediment samples; (D) Relationship between $\mathrm{Hg}$ concentration in the surface sediments and the 2-16 $\mu \mathrm{m}$ grain size fraction (modified and redrawn from [19]).

Table 2. Ranges of $\mathrm{Hg}$ concentration in surface sediments from this study compared to local areas of the Gulf of Trieste and other similar environments in the world as reported in the literature.

\begin{tabular}{lc}
\hline \multicolumn{1}{c}{ Location } & $\mathbf{H g}\left(\boldsymbol{\mu g} \mathbf{g}^{-\mathbf{1}} \mathbf{)}\right.$ \\
\hline Bay of Panzano (Italy)-this study & $0.77-6.39$ \\
Bay of Panzano (Italy)-[30] & $0.30-13.5$ \\
Bay of Panzano (Italy)-stations D0, D2, E3-[52] & $1.40-5.54$ \\
Timavo estuary (Italy)-[53] & $0.08-2.40$ \\
Isonzo River mouth (Italy)-[23] & $2.76-10.2$ \\
Isonzo River mouth (Italy)-stations A4, IS1, IS2-[52] & $4.92-6.18$ \\
Marano and Grado Lagoon (Italy)-[17] * & $0.68-9.95$ \\
Grado Lagoon (Italy)-[54]** & $9.50-14.4$ \\
Marano Lagoon (Italy)-[17] & $1.22-4.49$ \\
Aussa River, Marano Lagoon (Italy)-[55] & $0.82-5.69$ \\
Gulf of Trieste (Italy)-stations A0, A2, A3-[52] & $0.54-1.24$ \\
Gulf of Trieste (Italy)-[19] & $0.10-23.3$ \\
Venice Lagoon (Italy)-[56] & $0.50-2.51$ \\
Gulf of Trieste (Slovenia)-[57] & $0.06-0.88$ \\
northern Adriatic Sea-[21] & $0.05-8.63$ \\
central Adriatic Sea-[21] & $0.02-0.13$ \\
southern Adriatic Sea-[21] & $0.03-0.07$ \\
Northern Tyrrhenian Sea coastal area (NE Latium, Italy)-[58] & $0.03-2.20$ \\
Thau Lagoon (France)-[59] & $0.30-0.46$ \\
Port of Cartagena (Spain)-[60] & $21.6-136$ \\
Port of Barcelona (Spain)-[60] & $0.94-4.12$ \\
Port of Coruña (Spain)-[60] & $0.54-6.41$ \\
Bay of Cádiz (Spain)-[61] & $0.77-1.18$ \\
Gulf of Cádiz (Spain)-[61] & $0.24-0.30$ \\
Nalón estuary (Spain)-[62] & $0.10-1.33$ \\
Jiaozhou Bay (China)-[11] & $0.02-0.15$ \\
Jinzhou Bay (China)-[11] & $0.80-25.0$ \\
Chesapeake Bay (USA)-[63] & $0.08-0.18$ \\
\hline 0-1 cm surface sediment;* 0-10 cm surfar & \\
\hline
\end{tabular}

${ }^{*} 0-1 \mathrm{~cm}$ surface sediment; ${ }^{* *} 0-10 \mathrm{~cm}$ surface sediment. 
The concentration of $\mathrm{Hg}$ in the surface sediments investigated in this study (0.77$6.39 \mu \mathrm{g} \mathrm{g}^{-1}$, Figure 3) exceeded the Italian regulatory threshold limit of $0.30 \mu \mathrm{g} \mathrm{g}^{-1}$ (Decrees of the Italian Ministry of the Environment 260/2010 and 172/2015 according to EU Directive 2000/60/EC). Although the results from this study testified to a total $\mathrm{Hg}$ concentration in the surface sediments which remains of concern, speciation analyses performed on sediments collected along the main access channel to the Port of Monfalcone recently demonstrated that the element appeared to be strongly associated with the less mobile chemical fractions [30]. This suggested that most of the $\mathrm{Hg}$ in the investigated sediments was not available for $\mathrm{MeHg}$ production unless under conditions of anoxia [32]. Indeed, the methylation rate does not only depend on the total amount of $\mathrm{Hg}[17,19,30]$ since several factors (e.g., temperature, $\mathrm{pH}$, Eh, dissolved oxygen) may also have a role in $\mathrm{MeHg}$ production $[47,64]$.

Mercury values of the same order of magnitude were also reported for the surface sediments of the Bay of Panzano (1.40-5.54 $\mathrm{\mu g} \mathrm{g}^{-1}$, [52]) as well as for the northern Adriatic Sea [21] (Table 2). Conversely, notably lower values were found both in the central and southern sector of the Adriatic Sea [21] as well as the northern Tyrrhenian Sea [58] and at other marine coastal areas and estuarine environments worldwide (Table 2).

The amount of $\mathrm{Hg}$ in the investigated surface sediments was comparable to that observed in the offshore sector of the Gulf (ranging between 0.10 and $11.7 \mu^{-1} \mathrm{~g}^{-1}$, [19]) and significantly lower with respect to the Isonzo River mouth where the highest concentrations of $\mathrm{Hg}$ were observed in previous research (ranging between 4.45 and $23.3 \mu \mathrm{g} \mathrm{g}^{-1}$, [19]) (Figure 3), and primarily related to the occurrence of the detrital form of $\mathrm{Hg}$ (cinnabar particles) [37].

According to the linear function displaying the relationship between the concentration of $\mathrm{Hg}$ and the percentage of the 2-16 $\mu \mathrm{m}$ grain size fraction proposed by previous research, two groups of samples were identified [19] (Figure 3). The first included sediments collected at the Isonzo River mouth, whereas the second referred to sediments from the whole Gulf. The surface sediments investigated in this study belonged to the second group, confirming their common origin with respect to the offshore sediments of the Gulf of Trieste (Figure 3).

\subsection{Suspended Particulate Matter: Distribution and Hg Concentration}

No notable differences in the SPM were observed at the six investigated sites and the highest values were observed during sampling campaign 2 which was performed following a period of generally high discharge from the Isonzo River (Table S1). The surface-bottom SPM ratios were generally low and $<1$ both under unperturbed $(0.87 \pm 0.07$, $0.63 \pm 0.17$ and $0.72 \pm 0.17$ during sampling campaigns 1,3 and 4 , respectively) and perturbed environmental conditions (sampling campaign 5, $0.78 \pm 0.10$ ). Conversely, high surface-bottom SPM ratios were observed following a period of high river discharge at the beginning of March (sampling campaign 2, $1.94 \pm 0.94$ with maximum values of 3.59 and 2.45 at sites P1 and P2, respectively) as a result of high freshwater and SPM inputs from the Isonzo River. This confirms that the SPM distribution in the investigated area depends heavily on the river discharge, as also suggested by the PCA output (Figure 4) and the significant correlation $(\mathrm{N}=30, \mathrm{r}=0.734, p<0.01$; on average $\mathrm{N}=5, \mathrm{r}=0.995$, $p<0.01$ ) observed between the average SPM concentration in the surface water at the six investigated sites and the Isonzo River discharge during the 5 sampling campaigns (Figure 5A).

The highest concentrations of PHg were observed under perturbed conditions during sampling campaign 2, both in the surface water $\left(8.37 \pm 2.11 \mathrm{ng} \mathrm{L}^{-1}\right)$ and at the bottom $\left(6.26 \pm 1.62 \mathrm{ng} \mathrm{L}^{-1}\right)$, especially at site P3 (12.5 and $8.64 \mathrm{ng} \mathrm{L}^{-1}$ in the surface water and at the bottom, respectively) (Figures 4 and 6). Moreover, a moderate correlation was observed between PHg and the Isonzo River discharge (Figure 5B; $\mathrm{N}=30, \mathrm{r}=0.644, p<0.01$; on average $\mathrm{N}=5, \mathrm{r}=0.761, p<0.5)$ as well as between PHg and the SPM concentration (Figure 5C; $\mathrm{N}=30, \mathrm{r}=0.634, p<0.01$; on average $\mathrm{N}=5, \mathrm{r}=0.927, p<0.1$ ) confirming the role of the Isonzo River as the primary source of $\mathrm{Hg}$ which enters the Gulf, mainly 
in the form of SPM, as highlighted by previous research $[22,36,65]$. Indeed, it has been demonstrated that the dispersion of $\mathrm{Hg}$ from the Isonzo River mouth depends heavily on the interaction between riverine and meteo-marine hydrological conditions and occurred following four principal directions, including in the direction of the Port of Monfalcone [19]. Consequently, suspended particles enriched in $\mathrm{Hg}$ were trapped in the Bay of Panzano, especially when winds such as the Scirocco and Libeccio are dominant.

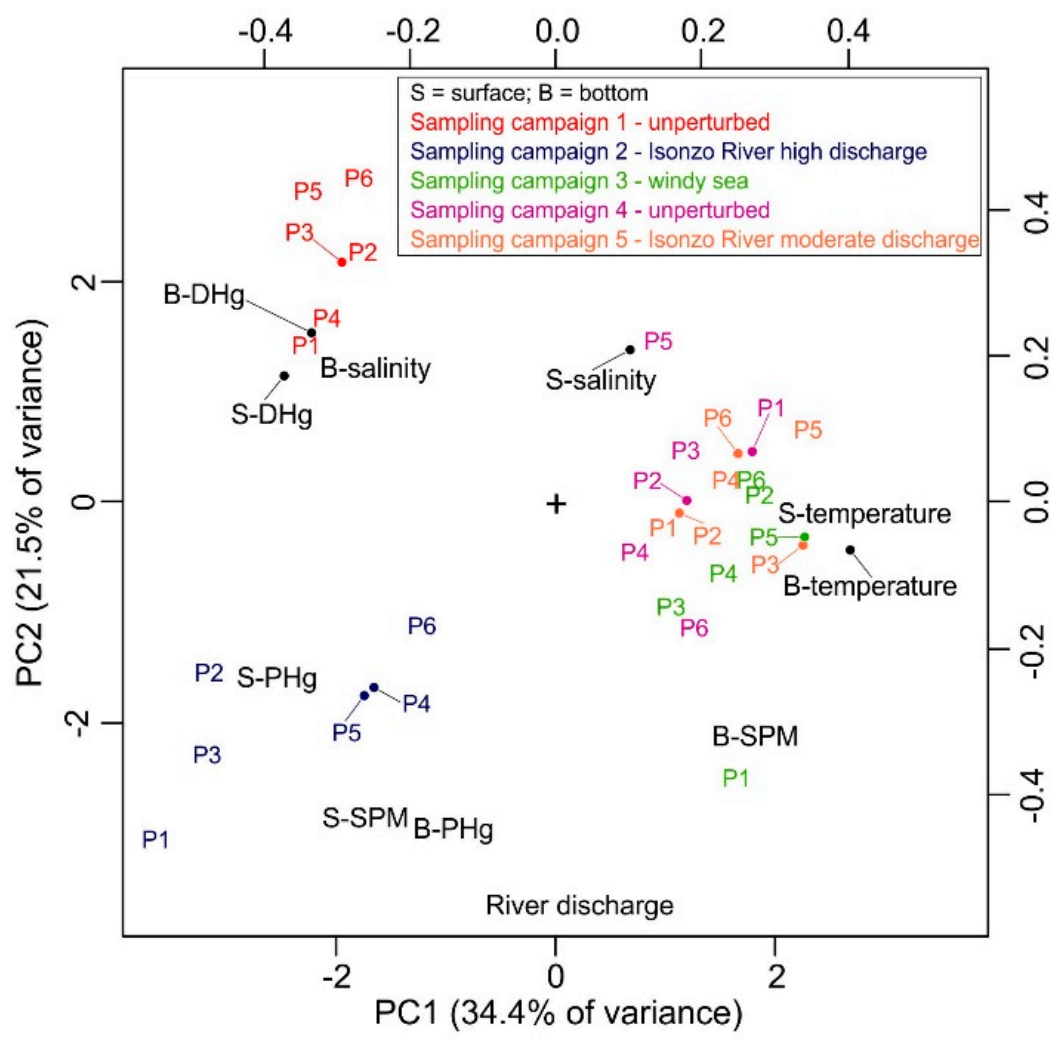

Figure 4. Biplot summarising the results of PCA performed on physico-chemical parameters (salinity, PSU; temperature, ${ }^{\circ} \mathrm{C}$; concentration of SPM, $\mathrm{mg} \mathrm{L}^{-1}$ ) dissolved and particulate $\mathrm{Hg}(\mathrm{DHg}$ and $\mathrm{PHg}$, ng $\mathrm{L}^{-1}$ ) observed in surface and bottom water samples collected at the six investigated sites (P1-P6) in the Bay of Panzano during sampling campaigns 1-5 performed under different environmental conditions.
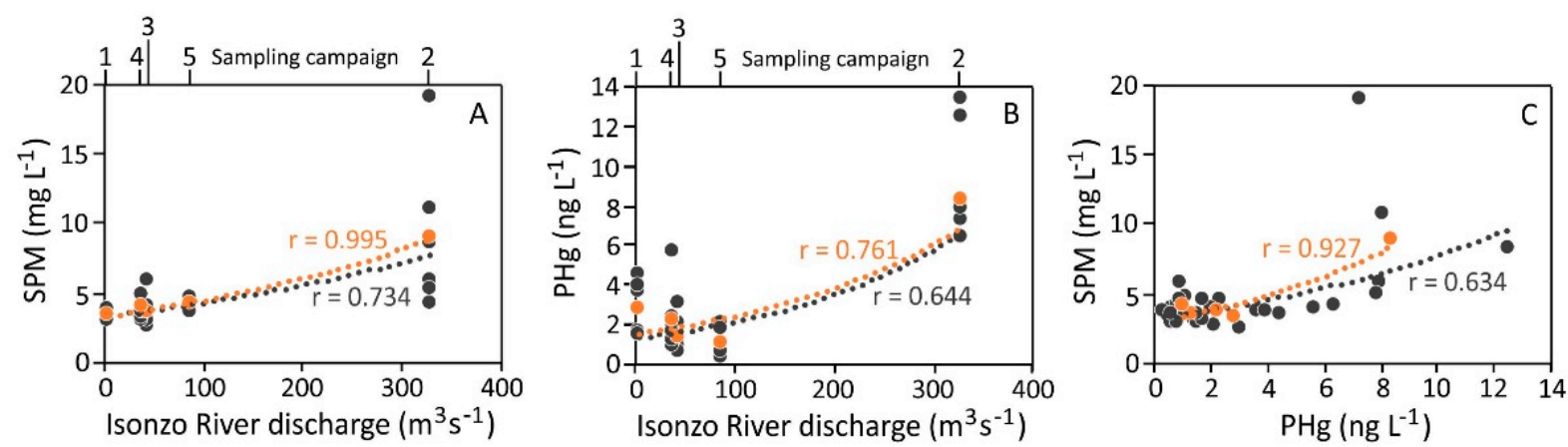

Figure 5. Correlation between the Isonzo River discharge $\left(\mathrm{m}^{3} \mathrm{~s}^{-1}\right)$ and (A) SPM concentration $\left(\mathrm{mg} \mathrm{L}^{-1}\right),(\mathbf{B}) \mathrm{PHg}$ concentration (ng L $\left.{ }^{-1}\right)$ and $(\mathbf{C})$ between the SPM concentration $\left(\mathrm{mg} \mathrm{L}^{-1}\right)$ and PHg concentration $\left(\mathrm{ng} \mathrm{L}^{-1}\right)$ in the surface water layer at the six investigated sites in the Bay of Panzano. Average SPM and PHg values and correlations are plotted in orange. Best fit was obtained using a 2nd-order polynomial curve. 

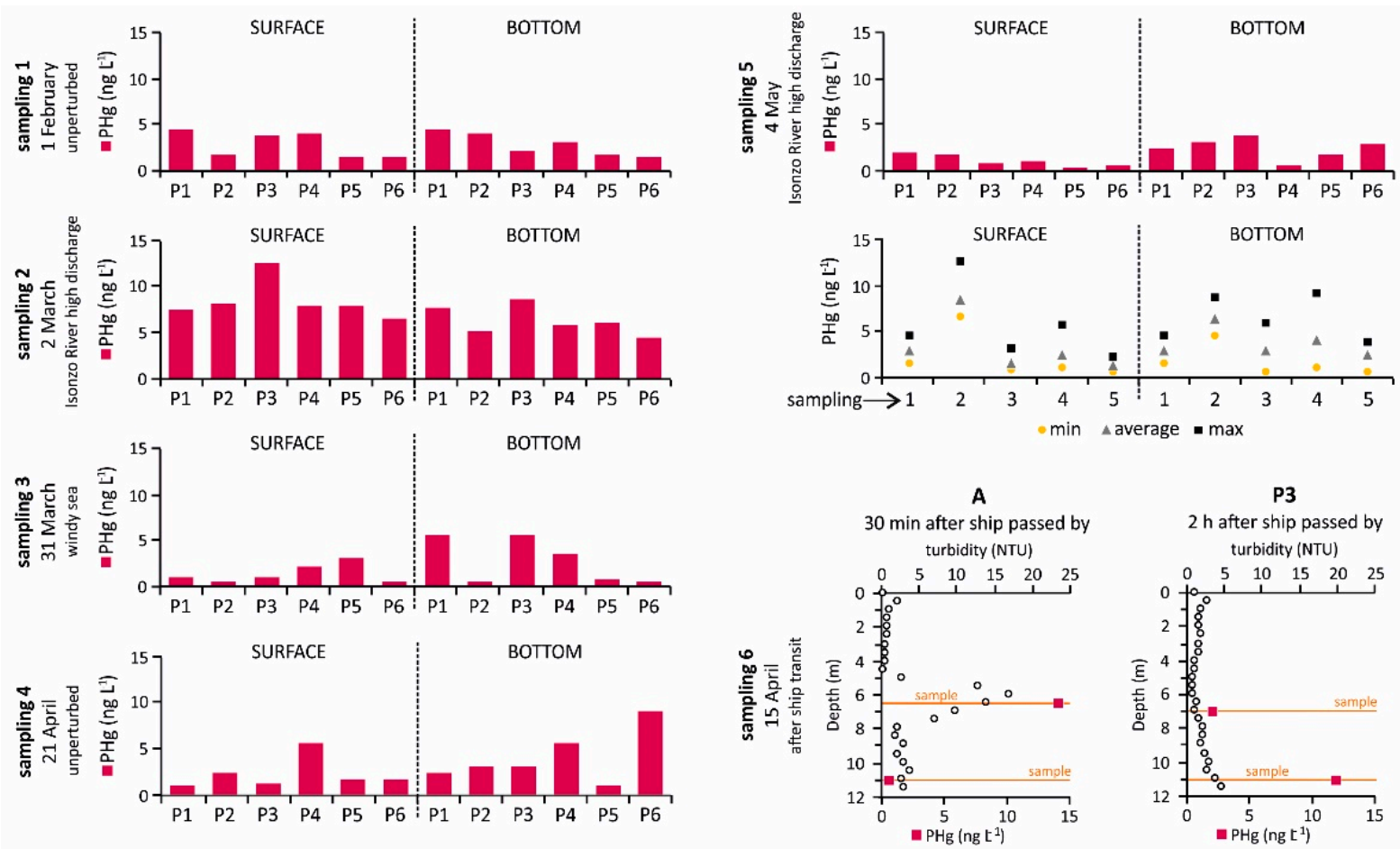

Figure 6. Concentration of $\mathrm{PHg}\left(\mathrm{ng} \mathrm{L}^{-1}\right)$ in the surface and bottom water samples collected at the six investigated sites in the Bay of Panzano under different environmental conditions during sampling campaigns 1-5 and concentrations of turbidity (NTU) and PHg (ng L ${ }^{-1}$ ) along the water column at sites A and P3 after a ship had sailed out of the area during sampling campaign 6 .

In this study, the maximum river discharge $\left(925 \mathrm{~m}^{3} \mathrm{~s}^{-1}\right)$ was reached approximately three weeks before sampling, remaining relatively elevated $\left(131-471 \mathrm{~m}^{3} \mathrm{~s}^{-1}\right)$ for several days after sampling campaign 2 . Accordingly, sampling campaign 5 was performed when the river discharge was moderate $\left(87.3 \mathrm{~m}^{3} \mathrm{~s}^{-1}\right)$ and slightly lower values of $\mathrm{PHg}$ were observed (1.11 \pm 0.66 and $2.42 \pm 1.15 \mathrm{ng} \mathrm{L}^{-1}$ in the surface and bottom water layers, respectively) (Figure 6). Moreover, the amount of $\mathrm{PHg}$ observed during sampling campaign 5 was found to be comparable to that of the sampling campaigns performed both under conditions of windy sea (sampling campaign 3) and under unperturbed conditions (sampling campaigns 1 and 4) (Figures 4 and 6). This suggests that relatively elevated values of $\mathrm{PHg}$ in the investigated area may be restricted to brief periods of particularly intense discharge from the Isonzo River, as evidenced by the PCA output (Figure 4) and the correlation between PHg and the river discharge (Figure 5B). Indeed, river flooding is responsible for large inputs of freshwater, SPM and particulate-associated contaminants [66,67]. In this context, it has been demonstrated that notable concentrations of $\mathrm{PHg}$ were discharged into the Gulf of Trieste during extreme Isonzo River flood events (maximum value of $49 \mu^{g^{-1}}$ following a river discharge of $1600 \mathrm{~m}^{3} \mathrm{~s}^{-1},[65]$ ).

Most likely due to dilution effects between riverine freshwater and saltwater, the $\mathrm{PHg}$ concentrations at the six investigated sites were generally found to be notably low with respect to those observed at the Isonzo River mouth by previous research [22,36], in front of the river mouth within a buoyant river plume [23] as well as along the Aussa River, flowing in the adjacent Marano Lagoon, which was affected by the discharge of $\mathrm{Hg}$ from a chlor-alkali plant $[17,55,68]$ (Table 3). Conversely, PHg values were found to be of the same order of magnitude with respect to the offshore marine area of the Gulf during a river plume event [23]. 
Table 3. Ranges of $\mathrm{Hg}$ concentration in the dissolved fraction $\left(\mathrm{DHg}, \mathrm{ng} \mathrm{L}{ }^{-1}\right)$ and in the $\mathrm{SPM}\left(\mathrm{PHg} \mu \mathrm{gg} \mathrm{g}^{-1}\right.$ and $\mathrm{ng} \mathrm{L}{ }^{-1}$ ) from this study compared to local areas of the Gulf of Trieste and other similar environments as reported in the literature.

\begin{tabular}{|c|c|c|c|c|}
\hline Location & Water Layer & $\mathrm{DHg}\left(\mathrm{ng} \mathrm{L^{-1 }}\right)$ & $\operatorname{PHg}\left(\operatorname{ng~L^{-1}}\right)$ & $\mathrm{PHg}\left(\mu \mathrm{g} \mathrm{g}^{-1}\right)$ \\
\hline \multirow{2}{*}{ Bay of Panzano (Italy)-this study } & surface & $<$ LOD-46.8 & $0.39-12.5$ & $0.10-1.55$ \\
\hline & bottom & $<$ LOD-149 & $2.42-3.73$ & $0.11-1.87$ \\
\hline \multirow{2}{*}{ Isonzo River mouth (Italy)-[22] } & surface & $0.46-17.0$ & $<$ LOD-97.6 & $0.09-37.3$ \\
\hline & bottom & $1.38-81.3$ & $<$ LOD-92.7 & n.s. \\
\hline \multirow{2}{*}{ Isonzo River mouth (Italy)-[23] } & surface & n.d. & n.s. -112 & $1.20-2.70$ \\
\hline & bottom & n.d. & $<1.00-84.0$ & $0.20-2.40$ \\
\hline \multirow{2}{*}{ Isonzo River mouth (Italy)-[36] } & surface & 6.25 & 105 & 12.1 \\
\hline & bottom & $<$ LOD-4.16 & $10.2-57.3$ & $1.45-1.59$ \\
\hline \multirow{2}{*}{ Timavo estuary (Italy)-[53] } & surface & $<\mathrm{LOD}-2.27$ & $2.91-4.30$ & $1.96-4.28$ \\
\hline & bottom & $<$ LOD-5.10 & $8.80-23.1$ & $1.78-2.57$ \\
\hline \multirow{2}{*}{ Gulf of Trieste (Italy)-[69] } & surface & $<\mathrm{LOD}-4.90$ & n.d. & \multirow{2}{*}{$0.05-0.56$} \\
\hline & bottom & $0.18-2.69$ & n.d. & \\
\hline Grado Lagoon inlet (Italy)-[70] & water column & $5.30-8.10$ & $5.80-160$ & n.s. \\
\hline Aussa River, Marano Lagoon & surface & $4.10-52.4$ & $3.40-131$ & $1.30-20.3$ \\
\hline (Italy)-[55] & bottom & $9.10-48.0$ & $4.80-32.1$ & $1.10-2.20$ \\
\hline Tagus Estuary (Portugal)-[71] & water column & $3.61-65.4$ & n.d. & $0.36-8.63$ \\
\hline Portuguese coast (Portugal)-[72] & surface & $1.00-28.1$ & n.d. & $0.80-15.3$ \\
\hline Tinto estuary (Spain)-[61] & surface & $1.66-19.8$ & n.d. & $0.06-1.12$ \\
\hline Odiel estuary (Spain)-[61] & surface & $3.29-40.0$ & n.d. & $0.14-6.52$ \\
\hline Gulf of Cádiz (Spain)- [61] & surface & $0.42-0.76$ & n.d. & $0.08-0.42$ \\
\hline \multirow{2}{*}{ Nalón estuary (Spain)-[73] } & surface & $2.13-5.09$ & $2.59-9.10$ & $0.25-2.35$ \\
\hline & bottom & $0.74-7.73$ & $3.05-14.4$ & $0.43-2.69$ \\
\hline Jiaozhou Bay (China)-[11] & surface & $2.47-9.87$ & n.d. & $0.06-0.47$ \\
\hline New York/New Jersey Harbor-[7] & surface & $0.34-1.00$ & $2.91-64.6$ & $0.08-1.78$ \\
\hline New York/New Jersey Harbor-[7] & bottom & $<$ LOD-3.01 & $4.47-295$ & $0.19-2.43$ \\
\hline
\end{tabular}

n.d.: not determined; n.s.: not specified.

As previously mentioned, a ship with a large draught $(8 \mathrm{~m})$ moving through the main access channel to the port area may temporarily affect the turbidity vertical distribution along the water column, reaching the maximum values at approximately $7 \mathrm{~m}$ depth at site A (Figure 2). The water sample collected at the maximum turbidity zone showed a $\mathrm{PHg}$ concentration of $14.0 \mathrm{ng} \mathrm{L}^{-1}$, which was two orders of magnitude higher than the $\mathrm{PHg}$ at the bottom ( $\left.0.55 \mathrm{ng} \mathrm{L}^{-1}\right)$ (Figure 6). Approximately $2 \mathrm{~h}$ after the ship had sailed out of the area, the $\mathrm{PHg}$ concentration at the same depth (approximately $7 \mathrm{~m}$ ) at site $\mathrm{P} 3$ was notably lower $\left(2.01 \mathrm{ng} \mathrm{L}^{-1}\right)$, confirming that unperturbed conditions were restored after a brief period of time. However, a higher $\mathrm{PHg}$ concentration was observed at the bottom (11.8 $\mathrm{ng} \mathrm{L}^{-1}$ ), most likely due to the settling of fine $\mathrm{Hg}$ enriched particles (Figure 6).

\subsection{Dissolved $\mathrm{Hg}$}

The occurrence of $\mathrm{DHg}$ at the six sampling sites was investigated during unperturbed and perturbed environmental conditions both in the surface water and at the bottom (Figure 7; Table S1). The highest concentrations of $\mathrm{DHg}$ were detected in winter both under unperturbed (sampling campaign 1, 25.9 \pm 10.2 and $35.9 \pm 37.4 \mathrm{ng} \mathrm{L}^{-1}$ in the surface water and at the bottom, respectively; Figure 4 ) and perturbed conditions (sampling campaign 2, $16.5 \pm 16.4$ and $40.1 \pm 59.5 \mathrm{ng} \mathrm{L}^{-1}$ in the surface water and at the bottom, respectively), reaching the maximum concentration in the bottom saltwater at sites P5 (sampling campaign 1, $112 \mathrm{ng} \mathrm{L}^{-1}$ ) and P2 (sampling campaign 2, $149 \mathrm{ng} \mathrm{L}^{-1}$ ) (Figures 4 and 7). Dissolved $\mathrm{Hg}$ concentrations were one order of magnitude lower in spring both under unperturbed (sampling campaign 4, $4.74 \pm 1.59$ and $5.20 \pm 7.31 \mathrm{ng} \mathrm{L}^{-1}$ in the surface water and at the bottom, respectively) and perturbed conditions (sampling campaign 5, $4.21 \pm 3.17$ and $3.72 \pm 1.86 \mathrm{ng} \mathrm{L}^{-1}$ in the surface water and at the bottom, respectively) (Figure 7). 

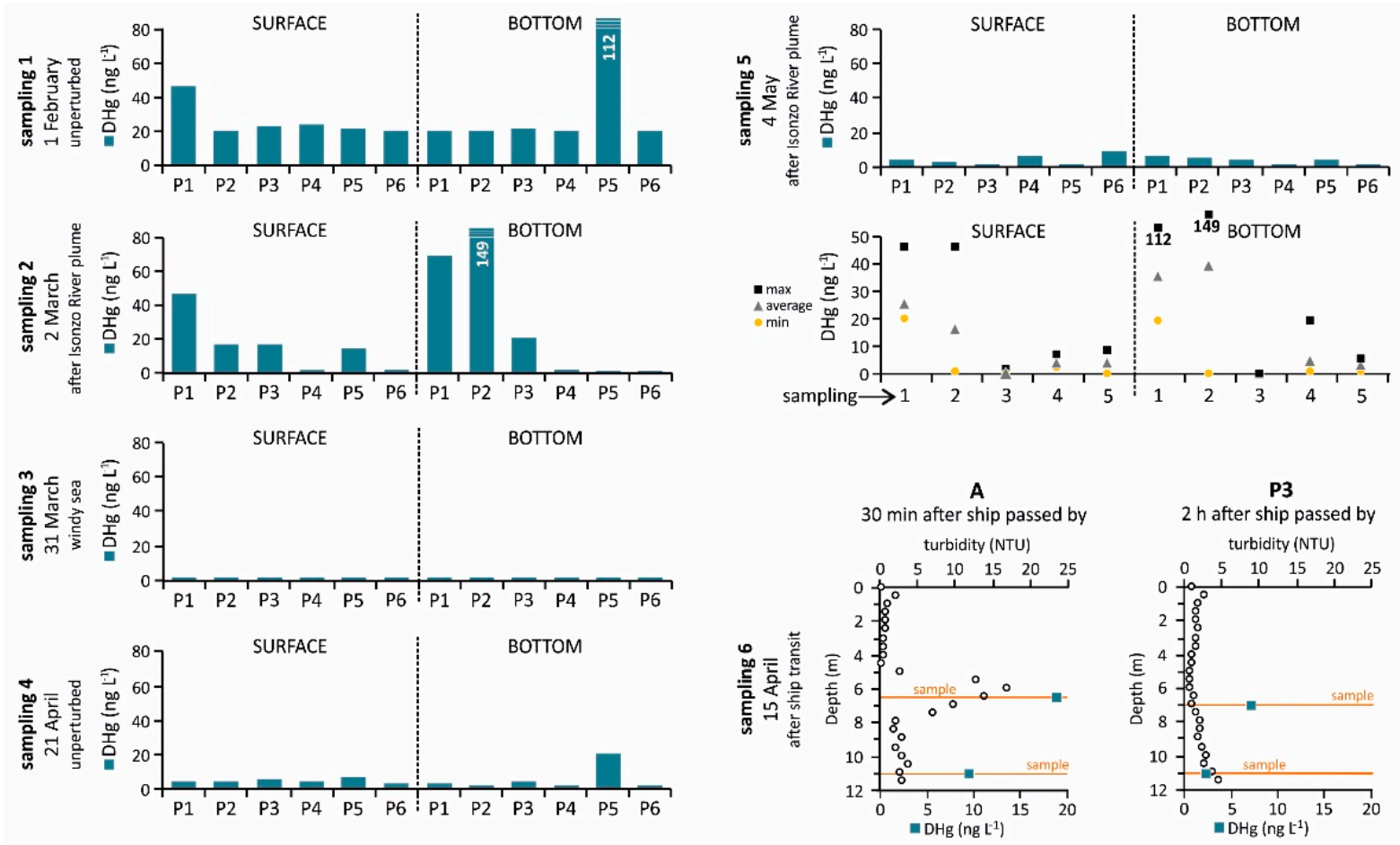

Figure 7. Concentration of $\mathrm{DHg}\left(\mathrm{ng} \mathrm{L}^{-1}\right)$ in the surface and bottom water samples collected at the six investigated sites in the Bay of Panzano under different environmental conditions. The " " symbol represents the single measurements of turbidity, as reported in the $x$-axis in the figure.

Conversely, DHg was mainly $<\mathrm{LOD}$ during the sampling campaign performed at the end of March (sampling campaign 3) (Figure 7), most likely due to the intense windy conditions during sampling operations. Indeed, turbulence induced by wind [74] and the subsequent mixing of the water column [75] may promote the release of gaseous elemental $\mathrm{Hg}$ from the surface water to the atmosphere, although the highest $\mathrm{Hg}$ evasion was found to occur in summer [48,76]. Moreover, sampling campaign 3 was performed following a period of low discharge from the Isonzo River $\left(<100 \mathrm{~m}^{3} \mathrm{~s}^{-1}\right)$ and relatively low $\mathrm{PHg}$ concentrations were observed $\left(1.42 \pm 0.97\right.$ and $2.81 \pm 2.51 \mathrm{ng} \mathrm{L}^{-1}$ in the surface and bottom water layers, respectively). This suggests that low amounts of $\mathrm{PHg}$ were available to desorption and or dissolution processes with subsequent limiting of $\mathrm{Hg}$ release from the suspended particles to the dissolved fraction.

Dissolved $\mathrm{Hg}$ concentrations were of the same order of magnitude with respect to previous research focused on the Isonzo River mouth [22] and notably higher than those reported for the Gulf of Trieste [69] (Table 3). Generally, DHg at the investigated sites was higher compared to other aquatic systems along the Portuguese coast [72], the Tagus estuary [71], Tinto and Odiel estuaries [61] as well as the Gulf of Cádiz in Spain [61], especially in the bottom saltwater (Table 3).

As in the case of $\mathrm{PHg}$, DHg reached a concentration of $19.0 \mathrm{ng} \mathrm{L}^{-1}$ at approximately $7 \mathrm{~m}$ depth where the maximum turbidity zone was observed at site A after a ship had left the area during sampling campaign 6, decreasing at the bottom $\left(9.40 \mathrm{ng} \mathrm{L}^{-1}\right)$. Notably lower values were found both at $7 \mathrm{~m}$ depth $\left(7.11 \mathrm{ng} \mathrm{L}^{-1}\right)$ and at the bottom $\left(2.35 \mathrm{ng} \mathrm{L}^{-1}\right)$ at site P3 approximately $2 \mathrm{~h}$ after a ship had passed by (Figure 7).

\subsection{Mercury Partitioning between the Suspended Particulate Matter and the Dissolved Fraction: Distribution Coefficients $\left(K_{D}\right)$}

In aquatic systems, the partitioning behaviour of trace elements is mainly governed by adsorption/precipitation and desorption/dissolution processes. Indeed, trace elements can be preferentially associated with suspended particles (solid phase) and the dissolved 
fraction [77-79]. In this context, distribution coefficients $\left(K_{D}, \mathrm{~L} \mathrm{~kg}^{-1}\right)$ are commonly employed to investigate trace element partitioning behaviour, although information regarding the element chemical form is not provided by this index.

According to the Equation (1), $\mathrm{Hg}$ distribution coefficients $\left(K_{D}, \mathrm{~L} \mathrm{~kg}^{-1}\right)$ were calculated as the ratio between $\mathrm{Hg}$ concentration in the SPM $\left(P H g, \mu \mathrm{g} \mathrm{g}^{-1}\right)$ and in the dissolved fraction $\left(\mathrm{DHg}_{\mathrm{g}} \mathrm{ng} \mathrm{L}^{-1}\right)$ and expressed on a logarithmic scale [77] (Table 4):

$$
\log K_{D}=[P H g] /[D H g]
$$

Table 4. $\operatorname{LogK}_{\mathrm{D}}\left(\mathrm{L} \mathrm{kg}^{-1}\right)$ for $\mathrm{Hg}$ in the surface and bottom water samples collected at the six investigated sites in the Bay of Panzano under different environmental conditions.

\begin{tabular}{llcccccc}
\hline Sampling Campaign & Water Layer & P1 & P2 & P3 & P4 & P5 & P6 \\
1-1 February & surface & 4.45 & 4.41 & 4.64 & 4.65 & 4.34 & 4.41 \\
& bottom & 4.70 & 4.69 & 4.38 & 4.52 & 3.69 & 4.29 \\
2-2 March & surface & 3.92 & 4.64 & 4.96 & 6.07 & 5.02 & 5.77 \\
& bottom & 4.33 & 3.88 & 4.96 & 5.93 & 6.68 & 6.58 \\
3-31 March & surface & 4.97 & 5.74 & 5.99 & 6.42 & 6.01 & 5.86 \\
& bottom & 6.22 & 5.68 & 6.61 & 6.28 & 5.70 & 5.60 \\
4-21 April & surface & 4.88 & 5.14 & 4.60 & 5.52 & 4.88 & 5.16 \\
& bottom & 5.10 & 5.60 & 5.18 & 5.88 & 4.11 & 5.96 \\
5-4 May & surface & 5.12 & 5.06 & 5.83 & 4.48 & 4.72 & 4.32 \\
& bottom & 4.86 & 5.03 & 5.22 & 4.97 & 4.93 & 5.40 \\
\hline
\end{tabular}

At the six investigated sites and under different environmental conditions, $\log \mathrm{K}_{\mathrm{D}}$ values ranged overall between 3.92 and 6.42 and between 3.69 and 6.68 in the surface and bottom water layers, respectively (Table 4 ).

The $\log K_{\mathrm{D}}$ values were relatively high, thus testifying to the preferential partitioning of $\mathrm{Hg}$ in the suspended particles as also observed at the Isonzo River mouth [36] and other similar environments such as the New York/New Jersey Harbor, where Hg was found to be mainly associated with the SPM (98-99\%) [7]. In addition, the distribution of DHg in the surface water did not appear to be simply governed by salinity, since $\mathrm{Hg}$ is generally high particle reactive and easily involved in removal processes through adsorption and/or precipitation $[7,11,48,61]$. A significant correlation was observed between $\log \mathrm{K}_{\mathrm{D}}$ and $\mathrm{DHg}$ $(\mathrm{N}=60, \mathrm{r}=0.897, p<0.01)$, especially following periods of high freshwater discharge from the Isonzo River (sampling campaigns 2 and 5) (Figure 8), although the $\log \mathrm{K}_{\mathrm{D}}$ values did not notably vary among different sampling conditions.
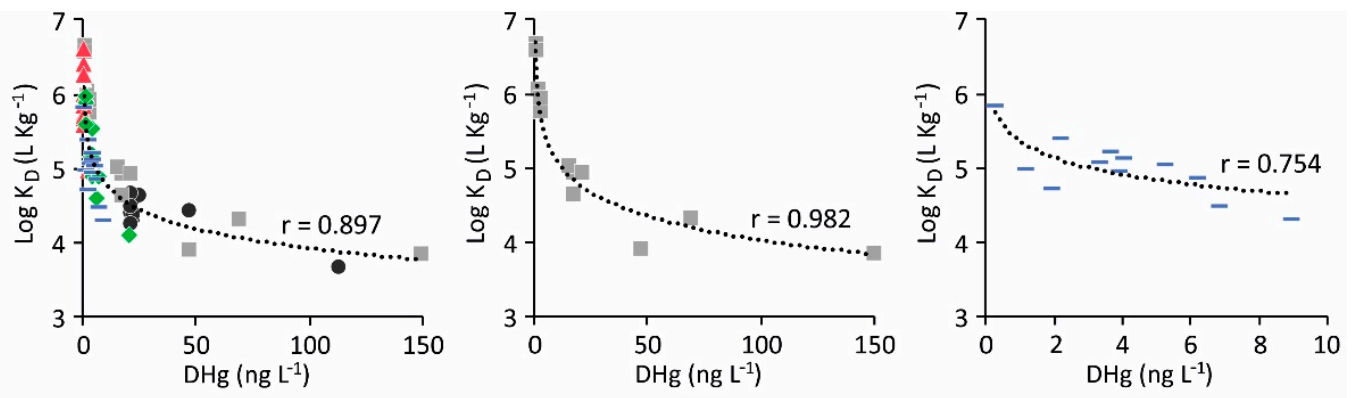

- Sampling campaign 1 a Sampling campaign $2 \Delta$ Sampling campaign 3 Sampling campaign $4 \quad$ Sampling campaign 5

Figure 8. Relationship between $\log \mathrm{KD}$ and dissolved $\mathrm{DHg}\left(\mathrm{ng} \mathrm{L}^{-1}\right)$ in surface and bottom water samples collected at the six investigated sites in the Bay of Panzano during sampling campaigns 1-5 performed under different environmental conditions. Best fit was obtained using a 2nd-order polynomial curve. 


\section{Conclusions}

The occurrence of $\mathrm{Hg}$ in the coastal area of the Gulf of Trieste still remains an issue of environmental concern, although extraction activities at the Idrija $\mathrm{Hg}$ mine (Slovenia) ceased in 1996.

Results from this research confirmed the role of the Isonzo River as the primary source of both dissolved and particulate $\mathrm{Hg}$ in the northernmost sector of the Gulf of Trieste (Bay of Panzano), especially following periods of high discharge of the river. However, contrary to $\mathrm{DHg}$, which showed both a notable spatial and temporal variability $\left(<\mathrm{LOD}-149 \mathrm{ng} \mathrm{L}^{-1}\right)$, the amount of PHg (0.39-12.5 $\left.\mathrm{ng} \mathrm{L}^{-1}\right)$ appeared to be strongly related to the river inputs of freshwater and SPM. Indeed, the highest amounts of PHg both in the surface water and at the bottom were found to be restricted to brief periods of intense river discharge. In agreement with previous investigations, $\mathrm{Hg}$ in the water column was still found to be mainly partitioned in the SPM, as also confirmed by the elevated $\log K_{D}$ values (3.696.68), thus testifying to its behaviour as showing a high affinity for fine sediment particles transported in suspension.

At the investigated area in the Bay of Panzano, the relatively shallow water depth allowed $\mathrm{PHg}$ accumulation in the surface sediments, which showed remarkable $\mathrm{Hg}$ concentrations $\left(0.77-6.39 \mathrm{\mu g} \mathrm{g}^{-1}\right)$. However, the amount of $\mathrm{Hg}$ in the sediments was found to be notably low with respect to the littoral zone surrounding the Isonzo River mouth and of the same order of magnitude if compared to sediments from the offshore sector of the Gulf of Trieste.

Resuspension events caused by natural and anthropogenic factors certainly affect the mobility of $\mathrm{Hg}$ from the sediment compartment to the water column, but results from this research showed that they can be limited. Indeed, perturbed conditions along the water column due to the presence of a large draught ship approaching the port area lasted only a brief period of time (approximately $2 \mathrm{~h}$ ). The observed increase for both $\mathrm{PHg}$ and $\mathrm{DHg}$ in the water column is temporary since unperturbed conditions were promptly restored. This evidence suggests that a similar scenario would also occur for dredging activities where the effect in terms of widespread $\mathrm{Hg}$ in the water column should be restricted both to the operation area and time period.

Results from this research also suggested that the magnitude of a natural event, such as the increase in wave motion or extreme Isonzo River flood events, would alter $\mathrm{DHg}$ and $\mathrm{PHg}$ concentrations in the water column more significantly than a local perturbation caused by anthropogenic activities. Moreover, considering the degree of contamination reported for the Isonzo River basin [80,81], it may be expected that the metal will continue to be transported from inland to the Gulf's waters for the foreseeable future.

Since the Isonzo River's discharge conditions were identified as a crucial factor in regulating the amount of $\mathrm{Hg}$ in the northernmost sector of Gulf of Trieste, future research should address the effects of variations in the Isonzo River discharge on the contribution of $\mathrm{Hg}$ associated with the SPM as well as the evaluation of $\mathrm{Hg}$ and SPM fluxes in the investigated area.

Supplementary Materials: The following are available online at https:/ /www.mdpi.com/article/10 .3390/ijerph181910192/s1, Figure S1: Vertical profiles of turbidity (NTU, grey dots), salinity (PSU, blue line) and temperature $\left({ }^{\circ} \mathrm{C}\right.$, red line) recorded at the six investigated sites in the vicinity of the main access channel to the Port of Monfalcone (Bay of Panzano, Gulf of Trieste), Figure S2: Isonzo River daily discharge $\left(\mathrm{m}^{3} \mathrm{~s}^{-1}\right)$ and variations of salinity (PSU), temperature $\left({ }^{\circ} \mathrm{C}\right)$ and turbidity (NTU) at site P2 (surface and bottom water layers) and site P3 (surface water layer) between the 1 and 10 March 2016, Table S1: Mercury concentrations in the SPM (PHg, ng L ${ }^{-1}$ and $\mu \mathrm{g} \mathrm{g}^{-1}$ ) and in the dissolved fraction ( $\mathrm{DHg}, \mathrm{ng} \mathrm{L}^{-1}$ ) in the surface and bottom water samples collected at different sites in the vicinity of the main access channel to the Port of Monfalcone under different environmental conditions.

Author Contributions: Conceptualization, data curation, writing-original draft preparation, writing-review and editing, E.P. (Elena Pavoni) and S.C.; Methodology, formal analysis, E.P. 
(Elena Pavoni) and E.P. (Elisa Petranich); Data curation, software, E.P. (Elena Pavoni); Supervision, project administration, funding acquisition, S.S., S.C. and G.F. All authors have read and agreed to the published version of the manuscript.

Funding: This research received no external funding.

Institutional Review Board Statement: Not applicable.

Informed Consent Statement: Not applicable.

Data Availability Statement: The data presented in this study are available on request from the corresponding author.

Acknowledgments: We are grateful to Giacomo Casagrande and the Servizio Gestione Risorse Idriche of Friuli Venezia Giulia Region for providing discharge data for the Isonzo River. A special thanks to thank Gabriele Crevatin, Walter De Walderstein and Paolo De Carli for their technical assistance during sampling. Karry Close is warmly acknowledged for proofreading the manuscript.

Conflicts of Interest: The authors declare no conflict of interest.

\section{References}

1. Raj, D.; Maiti, S.K. Sources, Toxicity, and Remediation of Mercury: An Essence Review. Environ. Monit. Assess. 2019, 191, 566. [CrossRef]

2. Baumann, Z.; Jonsson, S.; Mason, R.P. Geochemistry of mercury in the marine environment. In Encyclopedia of Ocean Sciences, 3rd ed.; Cochran, J.K., Bokuniewicz, H.J., Yager, P.L., Eds.; Academic Press: Cambridge, MA, USA, 2019; pp. $301-308$.

3. Hatje, V.; Andrade, R.L.B.; Jesus, R.M.; Masqué, P.; Albergaria-Barbosa, A.C.R.; de Andrade, J.B.; Santos, A.C.S.S. Historical Records of Mercury Deposition in Dated Sediment Cores Reveal the Impacts of the Legacy and Present-Day Human Activities in Todos Os Santos Bay, Northeast Brazil. Mar. Pollut. Bull. 2019, 145, 396-406. [CrossRef]

4. Acquavita, A.; Floreani, F.; Covelli, S. Occurrence and Speciation of Arsenic and Mercury in Alluvial and Coastal Sediments. Curr. Opin. Environ. Sci. Health 2021, 22, 100272. [CrossRef]

5. Caplat, C.; Texier, H.; Barillier, D.; Lelievre, C. Heavy Metals Mobility in Harbour Contaminated Sediments: The Case of Port-En-Bessin. Mar. Pollut. Bull. 2005, 50, 504-511. [CrossRef] [PubMed]

6. Warnken, K.W.; Gill, G.A.; Griffin, L.L.; Santschi, P.H. Sediment-Water Exchange of Mn, Fe, Ni and Zn in Galveston Bay, Texas. Mar. Chem. 2001, 73, 215-231. [CrossRef]

7. Balcom, P.H.; Hammerschmidt, C.R.; Fitzgerald, W.F.; Lamborg, C.H.; O'Connor, J.S. Seasonal Distributions and Cycling of Mercury and Methylmercury in the Waters of New York/New Jersey Harbor Estuary. Mar. Chem. 2008, 109, 1-17. [CrossRef]

8. Cesário, R.; Monteiro, C.E.; Nogueira, M.; O’Driscoll, N.J.; Caetano, M.; Hintelmann, H.; Mota, A.M.; Canário, J. Mercury and Methylmercury Dynamics in Sediments on a Protected Area of Tagus Estuary (Portugal). Water Air Soil Pollut. 2016, $227,475$. [CrossRef]

9. Schäfer, J.; Castelle, S.; Blanc, G.; Dabrin, A.; Masson, M.; Lanceleur, L.; Bossy, C. Mercury Methylation in the Sediments of a Macrotidal Estuary (Gironde Estuary, South-West France). Estuar. Coast. Shelf Sci. 2010, 90, 80-92. [CrossRef]

10. Mason, R.P.; Benoit, J.M. Organomercury compounds in the environment. In Organometallics in the Environment; Craig, P., Ed.; John Wiley \& Sons: New York, NY, USA, 2003; pp. 57-99.

11. Mao, L.; Liu, X.; Wang, B.; Lin, C.; Xin, M.; Zhang, B.-T.; Wu, T.; He, M.; Ouyang, W. Occurrence and Risk Assessment of Total Mercury and Methylmercury in Surface Seawater and Sediments from the Jiaozhou Bay, Yellow Sea. Sci. Total Environ. 2020, 714, 136539. [CrossRef]

12. Choi, M.H.; Cech, J.J.; Lagunas-Solar, M.C. Bioavailability of Methylmercury to Sacramento Blackfish (Orthodon Microlepidotus): Dissolved Organic Carbon Effects. Environ. Toxicol. Chem. 1998, 17, 695-701. [CrossRef]

13. Hsu-Kim, H.; Kucharzyk, K.H.; Zhang, T.; Deshusses, M.A. Mechanisms Regulating Mercury Bioavailability for Methylating Microorganisms in the Aquatic Environment: A Critical Review. Environ. Sci. Technol. 2013, 47, 2441-2456. [CrossRef]

14. Baldi, F.; Bargagli, R.; Focardi, S.; Fossi, C. Mercury and Chlorinated Hydrocarbons in Sediments from the Bay of Naples and Adjacent Marine Areas. Mar. Pollut. Bull. 1983, 14, 108-111. [CrossRef]

15. Nelson, C.H.; Pierce, D.E.; Leong, K.W.; Wang, F.F.H. Mercury Distribution in Ancient and Modern Sediment of Northeastern Bering Sea. Mar. Geol. 1975, 18, 91-104. [CrossRef]

16. Guédron, S.; Huguet, L.; Vignati, D.A.L.; Liu, B.; Gimbert, F.; Ferrari, B.J.D.; Zonta, R.; Dominik, J. Tidal Cycling of Mercury and Methylmercury between Sediments and Water Column in the Venice Lagoon (Italy). Mar. Chem. 2012, 130-131, 1-11. [CrossRef]

17. Acquavita, A.; Covelli, S.; Emili, A.; Berto, D.; Faganeli, J.; Giani, M.; Horvat, M. Mercury in the Sediments of the Marano and Grado Lagoon (Northern Adriatic Sea): Sources, Distribution and Speciation. Estuar. Coast. Shelf Sci. 2012, 113, 20-31. [CrossRef]

18. Horvat, M.; Covelli, S.; Faganeli, J.; Logar, M.; Mandic, V.; Rajar, R. Mercury in Contaminated Coastal Environments; a Case Study: The Gulf of Trieste. Sci. Total Environ. 1999, 237-238, 43-56. [CrossRef]

19. Covelli, S.; Faganeli, J.; Horvat, M.; Brambati, A. Mercury Contamination of Coastal Sediments as the Result of Long-Term Cinnabar Mining Activity (Gulf of Trieste, Northern Adriatic Sea). Appl. Geochem. 2001, 16, 541-558. [CrossRef] 
20. Covelli, S.; Faganeli, J.; Horvat, M.; Brambati, A. Porewater Distribution and Benthic Flux Measurements of Mercury and Methylmercury in the Gulf of Trieste (Northern Adriatic Sea). Estuar. Coast. Shelf Sci. 1999, 48, 415-428. [CrossRef]

21. Ferrara, R.; Maserti, B.E. Mercury Concentration in the Water, Particulate Matter, Plankton and Sediment of the Adriatic Sea. Mar. Chem. 1992, 38, 237-249. [CrossRef]

22. Covelli, S.; Piani, R.; Kotnik, J.; Horvat, M.; Faganeli, J.; Brambati, A. Behaviour of Hg Species in a Microtidal Deltaic System: The Isonzo River Mouth (Northern Adriatic Sea). Sci. Total Environ. 2006, 368, 210-223. [CrossRef] [PubMed]

23. Covelli, S.; Piani, R.; Acquavita, A.; Predonzani, S.; Faganeli, J. Transport and Dispersion of Particulate Hg Associated with a River Plume in Coastal Northern Adriatic Environments. Mar. Pollut. Bull. 2007, 55, 436-450. [CrossRef]

24. Gosar, M.; Žibret, G. Mercury Contents in the Vertical Profiles through Alluvial Sediments as a Reflection of Mining in Idrija (Slovenia). J. Geochem. Explor. 2011, 110, 81-91. [CrossRef]

25. Kocman, D.; Kanduč, T.; Ogrinc, N.; Horvat, M. Distribution and Partitioning of Mercury in a River Catchment Impacted by Former Mercury Mining Activity. Biogeochemistry 2011, 104, 183-201. [CrossRef]

26. Gosar, M.; Teršič, T. Environmental Geochemistry Studies in the Area of Idrija Mercury Mine, Slovenia. Environ. Geochem. Health 2012, 34, 27-41. [CrossRef]

27. Baptista-Salazar, C.; Richard, J.-H.; Horf, M.; Rejc, M.; Gosar, M.; Biester, H. Grain-Size Dependence of Mercury Speciation in River Suspended Matter, Sediments and Soils in a Mercury Mining Area at Varying Hydrological Conditions. Appl. Geochem. 2017, 81, 132-142. [CrossRef]

28. Kotnik, J.; Horvat, M.; Dizdarevic, T. Current and Past Mercury Distribution in Air over the Idrija Hg Mine Region, Slovenia. Atmos. Environ. 2005, 39, 7570-7579. [CrossRef]

29. Horvat, M.; Jereb, V.; Fajon, V.; Logar, M.; Faganeli, J.; Hines, M.E.; Bonzongo, J.C. Mercury Distribution in Water, Sediment and Soil in the Idrijca and Soca River Systems. Geochem. Explor. Environ. Anal. 2002, 2, 287-296. [CrossRef]

30. Covelli, S.; Petranich, E.; Pavoni, E.; Signore, S. Can Sediments Contaminated by Mining Be a Source of Mercury in the Coastal Environment Due to Dredging? Evidence from Thermo-Desorption and Chemical Speciation. Bull. Environ. Contam. Toxicol. 2021, 106, 942-948. [CrossRef]

31. Emili, A.; Koron, N.; Covelli, S.; Faganeli, J.; Acquavita, A.; Predonzani, S.; Vittor, C.D. Does Anoxia Affect Mercury Cycling at the Sediment-Water Interface in the Gulf of Trieste (Northern Adriatic Sea)? Incubation Experiments Using Benthic Flux Chambers. Appl. Geochem. 2011, 26, 194-204. [CrossRef]

32. Emili, A.; Carrasco, L.; Acquavita, A.; Covelli, S. A Laboratory-Incubated Redox Oscillation Experiment to Investigate Hg Fluxes from Highly Contaminated Coastal Marine Sediments (Gulf of Trieste, Northern Adriatic Sea). Environ. Sci. Pollut. Res. 2014, 21, 4124-4133. [CrossRef] [PubMed]

33. Cozzi, S.; Falconi, C.; Comici, C.; Čermelj, B.; Kovac, N.; Turk, V.; Giani, M. Recent Evolution of River Discharges in the Gulf of Trieste and Their Potential Response to Climate Changes and Anthropogenic Pressure. Estuar. Coast. Shelf Sci. 2012, 115, 14-24. [CrossRef]

34. Olivotti, R.; Faganeli, J.; Malej, A. Impact of “Organic" Pollutants on Coastal Waters, Gulf of Trieste. Water Sci. Technol. 1986, 18, 57-68. [CrossRef]

35. Malačič, V.; Petelin, B. Climatic Circulation in the Gulf of Trieste (Northern Adriatic). J. Geophys. Res. 2009, 114, C07002. [CrossRef]

36. Pavoni, E.; Crosera, M.; Petranich, E.; Adami, G.; Faganeli, J.; Covelli, S. Partitioning and Mixing Behaviour of Trace Elements at the Isonzo/Soča River Mouth (Gulf of Trieste, Northern Adriatic Sea). Mar. Chem. 2020, 223, 103800. [CrossRef]

37. Biester, H.; Gosar, M.; Covelli, S. Mercury Speciation in Sediments Affected by Dumped Mining Residues in the Drainage Area of the Idrija Mercury Mine, Slovenia. Environ. Sci. Technol. 2000, 34, 3330-3336. [CrossRef]

38. Vidovic, J.; Nawrot, R.; Gallmetzer, I.; Haselmair, A.; Tomašových, A.; Stachowitsch, M. Anthropogenically Induced Environmental Changes in the Northeastern Adriatic Sea in the Last 500 Years (Panzano Bay, Gulf of Trieste). Biogeosciences 2016, 13, 5965-5981. [CrossRef]

39. Singh, N.; Turner, A. Trace Metals in Antifouling Paint Particles and Their Heterogeneous Contamination of Coastal Sediments. Mar. Pollut. Bull. 2009, 58, 559-564. [CrossRef]

40. EPA. Method 1631, Revison e. Mercury in Water by Oxidation, Purge and Trap, and Cold Vapor Atomic Fluorescence Spectrometry; EPA: Washington, DC, USA, 2002.

41. EPA. Method 7473 (SW-846) Mercury in Solids and Solutions by Thermal Decomposition, Amalgamation, and Atomic Absorption Spectrophotometry; EPA: Washington, DC, USA, 1998.

42. EPA. EPA Method 3052. Microwave Assisted Acid Digestion of Siliceous and Organically Based Matrices; EPA: Washington, DC, USA, 1996.

43. Oliveri, P.; Malegori, C.; Casale, M. Chemometrics: Multivariate Analysis of Chemical Data. In Chemical Analysis of Food, 2nd ed.; Pico, Y., Ed.; Elsevier: Amsterdam, The Netherlands, 2020; ISBN 978-0-12-813266-1.

44. Oliveri, P.; Malegori, C.; Casale, M. The Impact of Signal Pre-Processing on the Final Interpretation of Analytical Outcomes-A Tutorial. Anal. Chim. Acta 2019, 1058, 9-17. [CrossRef] [PubMed]

45. Leardi, R.; Melzi, C.; Polotti, G. CAT (Chemometric Agile Tool). Available online: http:/ /Gruppochemiometria.It/Index.Php/ Software (accessed on 3 August 2021).

46. Turner, A.; Millward, G.E. Particle Dynamics and Trace Metal Reactivity in Estuarine Plumes. Estuar. Coast. Shelf Sci. 2000, 50, 761-774. [CrossRef] 
47. Ullrich, S.M.; Tanton, T.W.; Abdrashitova, S.A. Mercury in the Aquatic Environment: A Review of Factors Affecting Methylation. Crit. Rev. Environ. Sci. Technol. 2001, 31, 241-293. [CrossRef]

48. Fitzgerald, W.F.; Lamborg, C.H.; Hammerschmidt, C.R. Marine Biogeochemical Cycling of Mercury. Chem. Rev. 2007, 107, 641-662. [CrossRef]

49. Giani, M.; Djakovac, T.; Degobbis, D.; Cozzi, S.; Solidoro, C.; Umani, S.F. Recent Changes in the Marine Ecosystems of the Northern Adriatic Sea. Estuar. Coast. Shelf Sci. 2012, 115, 1-13. [CrossRef]

50. Gabel, F.; Lorenz, S.; Stoll, S. Effects of Ship-Induced Waves on Aquatic Ecosystems. Sci. Total Environ. 2017, 601-602, 926-939. [CrossRef]

51. Shepard, F.P. Nomenclature Based on Sand-Silt-Clay Ratios. J. Sediment. Petrol. 1954, 24, 151-158.

52. Acquavita, A.; Predonzani, S.; Mattassi, G.; Rossin, P.; Tamberlich, F.; Falomo, J.; Valic, I. Heavy Metal Contents and Distribution in Coastal Sediments of the Gulf of Trieste (Northern Adriatic Sea, Italy). Water Air Soil Pollut. 2010, 211, 95-111. [CrossRef]

53. Pavoni, E.; Crosera, M.; Petranich, E.; Faganeli, J.; Klun, K.; Oliveri, P.; Covelli, S.; Adami, G. Distribution, Mobility and Fate of Trace Elements in an Estuarine System Under Anthropogenic Pressure: The Case of the Karstic Timavo River (Northern Adriatic Sea, Italy). Estuar. Coast. 2021, 44, 1831-1847. [CrossRef]

54. Covelli, S.; Faganeli, J.; De Vittor, C.; Predonzani, S.; Acquavita, A.; Horvat, M. Benthic Fluxes of Mercury Species in a Lagoon Environment (Grado Lagoon, Northern Adriatic Sea, Italy). Appl. Geochem. 2008, 23, 529-546. [CrossRef]

55. Covelli, S.; Acquavita, A.; Piani, R.; Predonzani, S.; De Vittor, C. Recent Contamination of Mercury in an Estuarine Environment (Marano Lagoon, Northern Adriatic, Italy). Estuar. Coast. Shelf Sci. 2009, 82, 273-284. [CrossRef]

56. Bloom, N.S.; Moretto, L.M.; Scopece, P.; Ugo, P. Seasonal Cycling of Mercury and Monomethyl Mercury in the Venice Lagoon (Italy). Mar. Chem. 2004, 91, 85-99. [CrossRef]

57. Faganeli, J.; Planinc, R.; Pezdič, J.; Smodiš, B.; Stegnar, P.; Ogorelec, B. Marine Geology of the Gulf of Trieste (Northern Adriatic) Geochemical Aspects. Mar. Geol. 1991, 99, 93-108. [CrossRef]

58. Scanu, S.; Piazzolla, D.; Frattarelli, F.M.; Mancini, E.; Tiralongo, F.; Brundo, M.V.; Tibullo, D.; Pecoraro, R.; Copat, C.; Ferrante, M.; et al. Mercury Enrichment in Sediments of the Coastal Area of Northern Latium, Italy. Bull. Environ. Contam. Toxicol. 2016, 96, 630-637. [CrossRef] [PubMed]

59. Muresan, B.; Cossa, D.; Jézéquel, D.; Prévot, F.; Kerbellec, S. The Biogeochemistry of Mercury at the Sediment-Water Interface in the Thau Lagoon. 1. Partition and Speciation. Estuar. Coast. Shelf Sci. 2007, 72, 472-484. [CrossRef]

60. Casado-Martınez, M.C.; Buceta, J.L.; Belzunce, M.J.; DelValls, T.A. Using Sediment Quality Guidelines for Dredged Material Management in Commercial Ports from Spain. Environ. Int. 2006, 32, 388-396. [CrossRef] [PubMed]

61. Cossa, D.; Elbaz-Poulichet, F.; Nieto, J.M. Mercury in the Tinto-Odiel Estuarine System (Gulf of Cádiz, Spain): Sources and Dispersion. Aquat. Geochem. 2001, 7, 1-12. [CrossRef]

62. Garcia-Ordiales, E.; Covelli, S.; Rico, J.M.; Roqueñí, N.; Fontolan, G.; Flor-Blanco, G.; Cienfuegos, P.; Loredo, J. Occurrence and Speciation of Arsenic and Mercury in Estuarine Sediments Affected by Mining Activities (Asturias, Northern Spain). Chemosphere 2018, 198, 281-289. [CrossRef]

63. Taylor, V.F.; Buckman, K.L.; Seelen, E.A.; Mazrui, N.M.; Balcom, P.H.; Mason, R.P.; Chen, C.Y. Organic Carbon Content Drives Methylmercury Levels in the Water Column and in Estuarine Food Webs across Latitudes in the Northeast United States. Environ. Pollut. 2019, 246, 639-649. [CrossRef]

64. Whalin, L.; Kim, E.-H.; Mason, R. Factors Influencing the Oxidation, Reduction, Methylation and Demethylation of Mercury Species in Coastal Waters. Mar. Chem. 2007, 107, 278-294. [CrossRef]

65. Rajar, R.; Zagar, D.; Sirca, A.; Horvat, M. Three-Dimensional Modelling of Mercury Cycling in the Gulf of Trieste. Sci. Total Environ. 2000, 260, 109-123. [CrossRef]

66. Zonta, R.; Collavini, F.; Zaggia, L.; Zuliani, A. The Effect of Floods on the Transport of Suspended Sediments and Contaminants: A Case Study from the Estuary of the Dese River (Venice Lagoon, Italy). Environ. Int. 2005, 31, 948-958. [CrossRef]

67. Turner, J.N.; Brewer, P.A.; Macklin, M.G. Fluvial-Controlled Metal and As Mobilisation, Dispersal and Storage in the Río Guadiamar, SW Spain and Its Implications for Long-Term Contaminant Fluxes to the Doñana Wetlands. Sci. Total Environ. 2008, 394, 144-161. [CrossRef]

68. Piani, R.; Covelli, S.; Biester, H. Mercury Contamination in Marano Lagoon (Northern Adriatic Sea, Italy): Source Identification by Analyses of Hg Phases. Appl. Geochem. 2005, 20, 1546-1559. [CrossRef]

69. Faganeli, J.; Horvat, M.; Covelli, S.; Fajon, V.; Logar, M.; Lipej, L.; Cermelj, B. Mercury and Methylmercury in the Gulf of Trieste (Northern Adriatic Sea). Sci. Total Environ. 2003, 304, 315-326. [CrossRef]

70. Turritto, A.; Acquavita, A.; Bezzi, A.; Covelli, S.; Fontolan, G.; Petranich, E.; Piani, R.; Pillon, S. Suspended Particulate Mercury Associated with Tidal Fluxes in a Lagoon Environment Impacted by Cinnabar Mining Activity (Northern Adriatic Sea). J. Environ. Sci. 2018, 68, 100-113. [CrossRef] [PubMed]

71. Cesário, R.; Mota, A.M.; Caetano, M.; Nogueira, M.; Canário, J. Mercury and Methylmercury Transport and Fate in the Water Column of Tagus Estuary (Portugal). Mar. Pollut. Bull. 2018, 127, 235-250. [CrossRef] [PubMed]

72. Santos-Echeandía, J.; Caetano, M.; Brito, P.; Canario, J.; Vale, C. The Relevance of Defining Trace Metal Baselines in Coastal Waters at a Regional Scale: The Case of the Portuguese Coast (SW Europe). Mar. Environ. Res. 2012, 79, 86-99. [CrossRef] [PubMed] 
73. Pavoni, E.; García-Ordiales, E.; Covelli, S.; Cienfuegos, P.; Roqueñí, N. Legacy of Past Mining Activity Affecting the Present Distribution of Dissolved and Particulate Mercury and Methylmercury in an Estuarine Environment (Nalón River, Northern Spain). Appl. Sci. 2021, 11, 4396. [CrossRef]

74. Kuss, J.; Schneider, B. Variability of the Gaseous Elemental Mercury Sea-Air Flux of the Baltic Sea. Environ. Sci. Technol. 2007, 41, 8018-8023. [CrossRef] [PubMed]

75. Soerensen, A.L.; Mason, R.P.; Balcom, P.H.; Sunderland, E.M. Drivers of Surface Ocean Mercury Concentrations and Air-Sea Exchange in the West Atlantic Ocean. Environ. Sci. Technol. 2013, 47, 7757-7765. [CrossRef] [PubMed]

76. Floreani, F.; Acquavita, A.; Petranich, E.; Covelli, S. Diurnal Fluxes of Gaseous Elemental Mercury from the Water-Air Interface in Coastal Environments of the Northern Adriatic Sea. Sci. Total Environ. 2019, 668, 925-935. [CrossRef]

77. Turner, A. Trace-Metal Partitioning in Estuaries: Importance of Salinity and Particle Concentration. Mar. Chem. 1996, 54, 27-39. [CrossRef]

78. EPA. Understanding Variation in Partition Coefficient, Kd, Values; EPA: Washington, DC, USA, 1999.

79. Gagnon, C.; Saulnier, I. Distribution and Fate of Metals in the Dispersion Plume of a Major Municipal Effluent. Environ. Pollut. 2003, 124, 47-55. [CrossRef]

80. Žibret, G.; Gosar, M. Calculation of the Mercury Accumulation in the Idrijca River Alluvial Plain Sediments. Sci. Total Environ. 2006, 368, 291-297. [CrossRef] [PubMed]

81. Žagar, D.; Knap, A.; Warwick, J.J.; Rajar, R.; Horvat, M.; Četina, M. Modelling of Mercury Transport and Transformation Processes in the Idrijca and Soča River System. Sci. Total Environ. 2006, 368, 149-163. [CrossRef] [PubMed] 